\title{
First phase of macroinvertebrate repopulation of Lake Orta (Buccione Basin) after liming
}

\author{
Anna Maria NOCENTINI, Angela BOGGERO, Giovanna DE MARGARITIS and Marcella GIANATTI \\ CNR Istituto Italiano di Idrobiologia, Largo Tonolli 50, 28922 Verbania Pallanza, Italy
}

\begin{abstract}
The research described here was performed during 1993 and 1994 in the context of studies on the recovery of Lake Orta from acidification after the liming conducted from May 1989 to June 1990. The causes of the pollution were due to the oxidation of ammonium sulphate discharged from a factory producing rayon by a cupro-ammoniacal method and to the loads of heavy metals (Cu, $\mathrm{Cr}, \mathrm{Ni}, \mathrm{Zn}$ ) derived from plating factories. One year after liming, an increase in $\mathrm{pH}$ and a marked decrease in metal concentrations were observed, and as a consequence some qualitative and quantitative changes were observed in $1992-93$ in the planctonic communities and in the littoral macrobenthic fauna. This paper presents qualitative and quantitative data on macrobenthos collected along a transect between the littoral and the maximal depth in the Buccione Basin, which was directly affected by the effluents of the rayon factory. The data revealed some quantitative repopulation of this community, especially along the littoral. Qualitatively, however, the macrobenthos was still quite poor, consisting essentially of Oligochaeta and Diptera Chironomidae. The former were rare and mainly represented by Naididae between 15 and $22 \mathrm{~m}$, while the Tubificidae were well represented in the littoral and the profundal zones. As regards the Chironomidae, the genera Procladius and Chironomus gr. thummi extended as far as the maximum depth, while others, such as Ablabesmyia, Parakiefferiella bathophila and Dicrotendipes gr. nervosus were mostly distributed in the littoral layers. Among the other taxonomic groups only the Trichoptera and the Diptera Ceratopogonidae were quantitatively significant. However, many systematic entities typical of the less polluted Italian subalpine lakes are still absent. In fact, the colonisation of Lake Orta by macrobenthic organisms is still influenced by the increased concentrations of heavy metals in the sediment precipitated from the water column. The research included analysis of lake water and sediments chemistry to obtain information on the trophic level of the environment.
\end{abstract}

Key words:Orta, acidification, liming, macroinvertebrate community

\section{INTRODUCTION}

\subsection{Historical information}

The first data we have on the benthic fauna of Lake Orta were provided by Parona (1880), in his report on a survey made by Pavesi (1879). The presence of some species of Tardigrada and Nematoda was recorded, along with that of Oligochaeta (Naididae and Aelosomatidae). Later on, in 1924, Colosi found the turbellarian Dendrocoelum lacteum to a depth of $120 \mathrm{~m}$. During the biological decline of the lake, which began in 1927, macro- and microbenthic organisms were primarily observed along the zone of the lake nearest the shoreline. Pini (quoted by Monti, 1930) recorded finding two species of Lamellibranchia (Anodonta palustris and Unio cusianus), and Baldi (1949) observed in the Buccione Basin larvae of Diptera Chironomidae along with Nematoda, and abundant Protozoa populations (Difflugia and Centropyxis).

An important contribution to our knowledge of the benthic fauna of the lake was made by Moretti (1954a, b), who studied the distribution of Trichoptera along the shore of the whole lake, in relation to some environmental parameters which were of fundamental importance in determining the presence of the various species. He found 13 species of Trichoptera in the top $2 \mathrm{~m}$; among them, only Mystacides azurea was numerically well-represented in most of the 28 stations selected. Ecnomus tenellus and Oecetis sp. were widely present but less abundant.

In addition to Trichoptera, other orders of Insecta were found, particularly Diptera Chironomidae, but also Hemiptera, Plecoptera, Odonata, Coleoptera, Megaloptera. There were also sporadic sightings of Porifera, Turbellaria Tricladida, Oligochaeta (Tubificidae), Protozoa and Copepoda.

The presence in large numbers of Trichoptera and Diptera Chironomidae in the benthic littoral community was confirmed by Oioli (1969), who also observed significant populations of Oligochaeta (especially Naididae). In addition, the presence of the following was recorded: Nemertea, Nematoda, Turbellaria, Irudinea, Hydracarina, Anphipoda, and some orders of Insecta, such as Collembola, Ephemeroptera, Plecoptera, Odonata, Coleoptera, Diptera (Ceratopogonidae, Limoniidae, Tipulidae).

Before the seventies, not much information was available on the benthic community in the deep zone of the lake. It was either found to be absent (Corbella et al. 1958), or essentially made up of Protozoa, Rotifera and Copepoda (Ruggiu 1969). However, in the winter (January-February) and summer (July) of 1971, some macroinvertebrates (Anphipoda, Diptera Chironomidae, Oligochaeta) were found between depths of 3 and $62 \mathrm{~m}$ 
at the mouths of some watercourses (Bonacina et al. 1988).

There were important changes in the deep benthic fauna at the beginning of the eighties, when a treatment plant was set up to recover ammoniacal nitrogen and to further reduce the copper loading, the reduction of which had begun in 1958. At the same time a plant for treating domestic and industrial sewage was activated on the western shore of the lake (Lacqua et al. 1983; Bonacina \& Bonomi 1985). Bonacina \& Bonomi (1984) had already recorded the presence of dense Oligochaeta populations, belonging to the species Tubifex tubifex, in the deep zone (between 20 and $140 \mathrm{~m}$ ) of the three lake basins.

In the same period, less important changes occurred in the littoral macrofauna, which in 1987-88 was still largely made up of Trichoptera and Diptera Chironomidae. Other taxonomic groups (Irudinea and Oligochaeta Tubificidae) were however more widespread round the lake shore, at least in the top $150 \mathrm{~cm}$ (Ballarè et al. 1992). In this period Chironomidae and Trichoptera were also well represented in the periphyton (Cattaneo 1992).

Research on the littoral macrofauna continued between 1990 and 1993, both during the liming operation and immediately following it. The results revealed that the positive effects of the recovery intervention observed on the chemistry of the lake, produced no significative changes in the benthic macrofauna, particularly from a qualitative point of view. However, there had been a certain numerical increase of some taxonomic groups already present in the community in the years prior to the recovery operation (Tesauro et al. 1995). A study of the littoral macrobenthos performed in 1998 (Bielli \& Tesauro 2001) essentially confirmed the data obtained in the previous studies.

After the liming intervention, two research projects were set up to verify the situation of the macrobenthic fauna colonising the deeper layers. The first performed in the Buccione Basin (De Margaritis 1995) and the second one extended to the whole lake basin (Sabolla 1998). The results showed that some groups of organisms, particularly Oligochaeta and Chironomidae, were well represented also in some areas of the sub-littoral and deep zones, where, however, the number of systematic entities forming these populations was still extremely small. Important information was also gained on the environmental quality of the sediments, which appear to be still partly affected by the toxic residues that had accumulated on the bottom as far back as the first stage of the pollution of the lake, but also since the liming intervention (Baudo et al. 1989, Baudo \& Beltrami 2001).

\subsection{Aims of the study}

With the 1993-94 research on the macrofauna of the Buccione Basin, the most southerly of the basins of
Lake Orta, it was intended to analyse the effects of liming on the structure of the populations established at different levels between the littoral and the deep zones. This basin, with a maximum depth of $35 \mathrm{~m}$ and sloping gently from the shore to the bottom, was particularly suitable for the purpose.

We decided to focus on this basin because this part of the lake was highly polluted by the discharge from the Bemberg factory, and via the River Lagna, from the numerous plating factories in the area. This impact was the cause of the major changes in the abiotic and biotic components at sediment level (Corbella et al. 1958; Bonacina et al. 1986). The liming, which was started in this basin, resulted in an immediate improvement in the water chemistry. In particular, an increase in $\mathrm{pH}$ and alkalinity was recorded, as well as a marked reduction in concentrations of heavy metals, especially copper and aluminium, and of ammonia nitrogen, encouraging the appearance of new taxonomic entities at plankton community level (Ambrosetti et al. 1992; Calderoni \& de Bernardi 1992). It was also important to verify the recovery times of the benthic macrofauna in this part of the lake, so that our knowledge of the state of this community could be subsequently extended to the other sectors of the lake.

Along with the study of the macrobenthos in the Buccione Basin, lake water and sediments chemistry were analysed to gain information on the quality and level of productivity of the environment after the recovery intervention.

\section{METHODS}

\subsection{Water parameters}

Lake water samples which was performed for the period 1993-94 for macrobenthic study continued in 1995. The samples were collected by Ruttner bottle almost monthly between the beginning of spring (MarchApril) and autumn (October-November) at station A (Fig. 1), at the point of maximum depth of the basin. On each date samples were taken at regular intervals (every $2 \mathrm{~m}$ ) in the layers between $0-10$ and $10-20 \mathrm{~m}$; the samples from each layer were mixed to give an integrated sample. In addition, a discrete sample was taken at the depth of $30 \mathrm{~m}$, close to the sediments. On every sampling date water transparency was also measured by Secchi disk.

Concentrations of nitrogen and total phosphorus, suspended particulate matter (total seston) and its components (organic carbon and nitrogen), and chlorophyll were measured on each sample.

Total nitrogen and phosphorus values were determined on non-filtered samples by spectrophotometry (Tartari \& Mosello 1997). The water samples used for estimating total seston and chlorophyll were first filtered through a plankton net of $126 \mu \mathrm{m}$ mesh size. The material of a size between 1 and $126 \mu \mathrm{m}$ was then concentrated by vacuum filtering on Whatman GF/C fibre- 
glass filters, previously combusted at $500{ }^{\circ} \mathrm{C}$. Total seston was measured gravimetrically, taking account of the weight of the filter before and after filtration, and the volume of water filtered. The filters were then analysed using a $\mathrm{CHN}$ elemental analyser to evaluate the content of organic carbon (POC) and nitrogen (PON) in the particulate matter (Bertoni \& Callieri 1982). The carbon/nitrogen ratio $(\mathrm{C} / \mathrm{N})$ was calculated on the data of the individual samples to find out the prevalent composition of the organic fraction of the seston. The inorganic fraction was estimated by gravimetry, subtracting from the total seston concentrations the POC values multiplied by a conversion factor (Lenz 1977). The chlorophyll concentrated on the filters was extracted with methanol and its content measured by spectrofluorimetry (Holm-Hansen \& Rieman 1978).

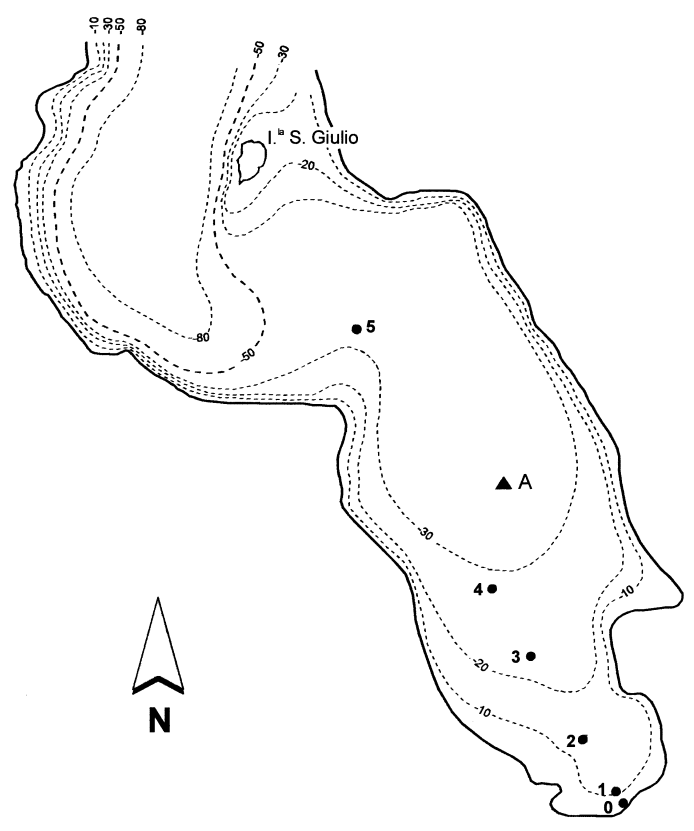

Fig. 1. Southern portion of Lake Orta. Location of the stations for sampling water $(A)$ and sediment $(0 \div 5)$.

\subsection{Sediment and macrobenthic community parameters}

The samples for studying the sediment and the macrobenthic fauna were taken at the same time in 6 stations $(0 \div 5)$, respectively at depths of $4,7,15,22,28$ and $35 \mathrm{~m}$, distributed along a northward transect between the shoreline and the island of S. Giulio (Fig. 1). Sampling was done seasonally in 1993 (March, July and November) and 1994 (March, July and October) by Ponar dredge (collection area: $420.25 \mathrm{~cm}^{2}$ ). Three samples were taken at each station and on each date: one for sediment analysis and two for the study of the macrobenthic fauna.

The samples to be used for sediment analysis were kept at $-20{ }^{\circ} \mathrm{C}$ until analysed; the macrobenthic samples were sieved through a $270 \mu \mathrm{m}$ mesh nylon net and fixed with enough neutral formaldehyde to prevent damage to the animals.
Each sediment sample was analysed for its concentrations of total organic matter, and for some parameters (organic and inorganic carbon and nitrogen, and plant pigments) which could give information on its origin and qualitative composition. It must be remembered that the organic matter in sediments is made up both of allochthonous elements from the surrounding land, and autochthonous elements from the pelagic layers, arriving via sedimentation, and from the littoral macrophyte vegetation. It is also the main food source of the macrobenthic populations, particularly of the detritivorous populations which are most closely associated with the sediment. Its qualitative and quantitative variations in time and space are thus a major factor in the settlement and growth of the populations. The calcium carbonate content was also estimated to verify whether the massive inputs of the element into the water column during the liming operation had resulted in its accumulation on the lake bottom. Each parameter was analysed on fractions of whole sediment taken from each sample. The analyses were done in triplicate and the values resulting for each parameter averaged.

The organic matter values were estimated as loss on ignition (LOI); the resulting weight difference was measured by heating to a temperature of $550^{\circ} \mathrm{C}$ a sample previously dried at $105{ }^{\circ} \mathrm{C}$ and weighed. The calcium carbonate concentrations were calculated by taking the same samples from a temperature of $550{ }^{\circ} \mathrm{C}$ to $950{ }^{\circ} \mathrm{C}$ and multiplying the resulting weight difference by the factor of 2.27 , which takes into account the loss of $\mathrm{CO}_{2}$ during combustion at high temperature (Wetzel 1970; Lewis \& Weiberhan 1981). The concentrations of organic matter and of carbonates are expressed as a percentage of the dry weight.

The content of organic carbon and nitrogen was evaluated by $\mathrm{CHN}$ elemental analyser on known quantities of sediment dried at $105{ }^{\circ} \mathrm{C}$, and that of inorganic carbon and nitrogen on samples combusted at $550{ }^{\circ} \mathrm{C}$. The resulting values are expressed as $\mu \mathrm{g}$ per $\mathrm{mg}$ of sediment, and as results from a simple proportion, the percent incidence of these parameters in the sample may be found. To evaluate the prevalent origin composition of the organic matter, the carbon/nitrogen ratio $(\mathrm{C} / \mathrm{N})$ 
Tab. 1. Monthly concentrations and annual means of total nitrogen (TN) and phosphorus (TP) in years $1993 \div 1995$.

\begin{tabular}{|c|c|c|c|c|c|c|}
\hline & \multicolumn{3}{|c|}{$\mathrm{TN}\left(\mathrm{mg} \mathrm{l}^{-1}\right)$} & \multicolumn{3}{|c|}{$\mathrm{TP}\left(\mu \mathrm{g}^{-1}\right)$} \\
\hline & $0-10 \mathrm{~m}$ & $10-20 \mathrm{~m}$ & $30 \mathrm{~m}$ & $0-10 \mathrm{~m}$ & $10-20 \mathrm{~m}$ & $30 \mathrm{~m}$ \\
\hline \multicolumn{7}{|l|}{1993} \\
\hline 25-Mar & - & - & - & - & - & - \\
\hline 03-May & 3.54 & 3.48 & 4.12 & 8.22 & 7.80 & 129.11 \\
\hline 20-May & 3.40 & 3.47 & 3.46 & 7.80 & 5.71 & 5.71 \\
\hline 21-Giu & 3.20 & 3.35 & 3.35 & 5.29 & 6.13 & 5.71 \\
\hline 26-Jul & 2.93 & 3.18 & 3.24 & 7.81 & 4.87 & 4.87 \\
\hline 31-Aug & 3.40 & 3.58 & 3.73 & 4.47 & 4.47 & 5.29 \\
\hline 30-Sep & 3.24 & 3.32 & 3.51 & 5.29 & 6.13 & 5.29 \\
\hline $25-$ Oct & 2.82 & 2.87 & 3.29 & 5.29 & 6.13 & 4.87 \\
\hline 04-Nov & 2.85 & 2.98 & 3.40 & 5.29 & 5.29 & 4.45 \\
\hline 17-Nov & 2.87 & 2.90 & 3.29 & 5.71 & 5.71 & 4.45 \\
\hline Annual mean & 3.14 & 3.24 & 3.49 & 6.13 & 5.80 & 18.86 \\
\hline \multicolumn{7}{|l|}{1994} \\
\hline 14-Mar & 3.02 & 2.99 & 3.02 & 4.45 & 4.87 & 4.87 \\
\hline 20-Apr & 3.07 & 3.07 & 3.02 & 5.29 & 5.29 & 5.29 \\
\hline 30-May & 3.04 & 3.13 & 3.17 & - & - & - \\
\hline 21-Giu & 2.94 & 2.93 & 3.05 & 5.84 & 5.84 & 5.84 \\
\hline 19-Jul & 2.91 & 3.08 & 3.17 & 3.34 & 5.84 & 6.26 \\
\hline 18-Aug & 2.68 & 2.77 & 2.90 & 4.59 & 4.59 & 5.01 \\
\hline 19-Sep & 2.71 & 2.79 & 2.97 & 5.01 & 5.42 & 4.59 \\
\hline 26-Oct & 2.77 & 2.81 & 3.09 & 3.34 & 3.34 & 2.92 \\
\hline Annual mean & 2.89 & 2.95 & 3.05 & 4.55 & 5.03 & 4.97 \\
\hline \multicolumn{7}{|l|}{1995} \\
\hline 03-Apr & 2.87 & 2.95 & 2.85 & 4.59 & 4.17 & 4.17 \\
\hline 26-Apr & 2.89 & 2.84 & 2.87 & 6.26 & 6.67 & 6.26 \\
\hline 24-May & 2.78 & 2.81 & 2.89 & 5.42 & 6.68 & 6.26 \\
\hline 21-Giu & 2.72 & 2.72 & 2.83 & 4.59 & 4.59 & 4.59 \\
\hline 19-Jul & 2.60 & 2.80 & 2.86 & 5.42 & 5.42 & 4.59 \\
\hline 24-Aug & 2.45 & 2.65 & 2.69 & 2.50 & 4.17 & 4.17 \\
\hline 21-Sep & 2.52 & 2.65 & 2.76 & 3.76 & 5.84 & 3.76 \\
\hline $18-O c t$ & 2.56 & 2.64 & 2.81 & 3.76 & 2.92 & 4.59 \\
\hline Annual mean & 2.67 & 2.76 & 2.82 & 4.54 & 5.06 & 4.80 \\
\hline
\end{tabular}

On each sample reserved for macrobenthos study, the organisms were sorted from the sediment, the individuals preserved in bottles containing neutral $10 \%$ formaldehyde, and then identified to species or other systematic entity level and counted to evaluate their numerical density. The individuals from each pair of samples were counted together. After being counted, the organisms were washed in water, dried on filter paper and weighed on a Mettler balance to estimate their biomass. Before each weighing, the larvae and pupae of the Trichoptera and the Chironomidae were removed from their cases. It should be stressed that the weight of organisms preserved in formaldehyde tends to be lower than their original weight (Donald \& Paterson 1977; Landhal \& Nagel 1978). The biomass was therefore calculated as wet weight in formaldehyde (Wingberg 1971). Numerical density is expressed as ind $\mathrm{m}^{-2}$, biomass as $\mathrm{mg} \mathrm{m}^{-2}$.

\section{RESULTS}

\subsection{Water parameters}

\subsubsection{Total nitrogen and phosphorus}

The mean total nitrogen concentrations along the water column showed a gradual decrease between 1993 and 1995 (Tab. 1).
In the top $20 \mathrm{~m}$, the values went from 3.2 to $2.8 \mathrm{mg}$ $\mathrm{N}^{-1}$. Slightly higher values (up to $3.05 \mathrm{mg} \mathrm{N}^{-1}$ ) were found in 1993 at the depth of $30 \mathrm{~m}$, where the samples were taken about $50 \mathrm{~cm}$ from the bottom. Over the three years of observation, seasonal variations were small along the whole column; the values were slightly higher between spring and summer in the top $20 \mathrm{~m}$ layer. The situation found in the Buccione Basin is reflected by the trend of the mean total nitrogen concentrations in the whole lake basin. Variations in time are closely related with those of nitrate, which after the liming and the dramatic reduction of ammonia nitrogen, is the most important component of the nitrogen cycle in the lake (Calderoni et al. 1997).

As regards total phosphorus concentrations along the column there was a slight decrease (Tab. 1). In 1993, mean total phosphorus content was between 5 and $6 \mu \mathrm{g}$

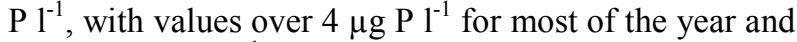
around $8 \mu \mathrm{g} \mathrm{P} \mathrm{l}^{-1}$ in the top $20 \mathrm{~m}$ in spring. The high value $\left(129 \mu \mathrm{g} \mathrm{P}^{-1}\right)$ recorded at $30 \mathrm{~m}$ in May has to be regarded as an isolated occurrence, probably caused by the release of phosphorus from the sediment following the decomposition of organic material accumulating on the bottom (Kelly 1991). In 1994 and 1995 the mean phosphorus content along the column fluctuated be- 


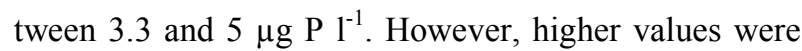
found in spring-summer 1994 and again in spring 1995.

Interestingly, no great variations in the mean total phosphorus content compared to the years prior to the liming have been recorded. In fact, it is likely that the increase in $\mathrm{pH}$ determined by the changes which have occurred in the lake's acid-base system has caused the precipitation of phosphorus in the sediment in the form of insoluble metal hydroxides, in particular of iron and aluminium (Calderoni \& Tartari 2001).

\subsubsection{Suspended particulate matter}

In the three years of this research, the mean concentration values of suspended particulate matter in the size range from 1 to $126 \mu \mathrm{m}$ were between 0.9 and $1.2 \mathrm{mg} \mathrm{l}^{-1}$ in the top $20 \mathrm{~m}$, and between 0.5 and 0.6 at $30 \mathrm{~m}$ (Tab. 2 ). In the top $20 \mathrm{~m}$ the total seston content showed marked variations during the year, with values up to 1.5 $\mathrm{mg} \mathrm{l}^{-1}$ in spring (April-May) and autumn (SeptemberOctober), and higher values in summer (June-August). The highest concentration $\left(3.7 \mathrm{mg} \mathrm{l}^{-1}\right)$ was measured in July 1993 during an algal bloom of the chlorophyceans Cosmarium tenue and Stichococcus minutissimus. At 30 $\mathrm{m}$ the total seston content showed lower seasonal variations, with the highest values (up to $0.9 \mathrm{mg} \mathrm{l}^{-1}$ ) in spring.

Tab. 2. Annual means recorded in years $1993 \div 1995$ for total seston, the inorganic and organic fraction, and the content in organic carbon and nitrogen, and in chlorophyll.

\begin{tabular}{lcccc}
\hline & Depth & \multicolumn{3}{c}{ Annual mean } \\
\cline { 3 - 5 } & $(\mathrm{m})$ & 1993 & 1994 & 1995 \\
\hline Total seston $\left(\mathrm{mg} \mathrm{l}^{-1}\right)$ & $0-10$ & 1.120 & 1.163 & 0.894 \\
& $10-20$ & 0.928 & 0.973 & 1.019 \\
& 30 & 0.607 & 0.594 & 0.616 \\
Inorganic seston $\left(\mathrm{mg} \mathrm{l}^{-1}\right)$ & $0-10$ & 0.344 & 0.377 & 0.401 \\
& $10-20$ & 0.350 & 0.302 & 0.517 \\
& 30 & 0.229 & 0.186 & 0.302 \\
Organic seston $\left(\mathrm{mg} \mathrm{l}^{-1}\right)$ & $0-10$ & 0.776 & 0.786 & 0.493 \\
& $10-20$ & 0.578 & 0.671 & 0.502 \\
& 30 & 0.378 & 0.407 & 0.314 \\
Organic carbon $\left(\mu \mathrm{g} \mathrm{l}^{-1}\right)$ & $0-10$ & 388 & 393 & 247 \\
& $10-20$ & 289 & 336 & 251 \\
Organic nitrogen $\left(\mu \mathrm{g}^{-1}\right)$ & 30 & 189 & 204 & 157 \\
& $0-10$ & 42 & 41 & 32 \\
& $10-20$ & 33 & 34 & 36 \\
C/N Ratio & 30 & 22 & 23 & 23 \\
& $0-10$ & 9 & 10 & 8 \\
Chlorophyll $\left(\mu \mathrm{g} \mathrm{l}^{-1}\right)$ & $10-20$ & 9 & 10 & 7 \\
& 30 & 9 & 9 & 7 \\
& $0-10$ & 4.2 & 3.3 & 2.0 \\
& $10-20$ & 3.5 & 5.0 & 3.2 \\
& 30 & 1.9 & 2.5 & 1.5 \\
\hline
\end{tabular}

The distribution in space and time of POC and PON, and chlorophyll, essentially reflects that of total seston (Tab. 2). On average, the highest content of these pa- rameters was found in the top $20 \mathrm{~m}$, with the highest values in spring-summer and autumn. Fairly high quantities $\left(\mathrm{POC}=1213 \mu \mathrm{g} \mathrm{l}^{-1}\right.$; PON $=125 \mu \mathrm{g} \mathrm{l}^{-1}$; $\mathrm{Chl}=15.5$ $\mu \mathrm{g}^{-1}$ ) were measured in July 1993, at the same time as the maximum observed for total seston, and in October $1994\left(\mathrm{POC}=684 \mu \mathrm{g} \mathrm{l}^{-1} ; \mathrm{PON}=92 \mu \mathrm{g} \mathrm{l}^{-1} ; \mathrm{Chl}=7.5 \mu \mathrm{g}\right.$ $\mathrm{l}^{-1}$ ), during a bloom of chlorophyceans and diatoms. However, mean concentrations of a certain importance were also measured at $30 \mathrm{~m}$, where living particulate matter is probably still well represented along with the matter deposited in the sediment from the water column.

An interesting observation is that the annual fluctuations of seston and its components (POC, PON and chlorophyll) essentially reflect the succession and the numerical participation during the year of the main taxonomic groups in the phytoplankton community, revealed by the seasonal variations in water transparency as measured by Secchi disk (Fig. 2). Important among the phytoplankton, both as regards density and biomass, are the chlorophyceans (present for most of the year), accompanied by crisophyceans in spring and by cyanophyceans and diatoms in summer-autumn (Morabito \& Curradi 1997; Morabito et al. 2001).

Elements of autochthonous origin, phytoplankton in particular, have undoubtedly made up a quantitatively significant fraction of the suspended particulate matter in this lake. This is suggested primarily by the relationships existing between the contents of POC, chlorophyll, and the organic fraction (Tab. 2). In 1993 and 1994 the concentrations of these elements maintained values which were on average higher than those found in 1995. Moreover, in the first two years the organic fraction represented on average between 60 and $70 \%$ of total seston, with contents above $60 \%$ for most of the year (Fig. 3). In contrast, PON concentrations along the water column remained at values which were more or less similar for the three years of the study.

The role of phytoplankton component in the organic fraction of the seston are also suggested by the values of the $\mathrm{C} / \mathrm{N}$ ratio measured along the column, which are on average between 9 and 10 in 1993 and 1994, and between 7 and 8 in 1995. The 1994 values of this ratio showed a seasonal variability higher than that observed in 1993 and 1995, reaching a maximum of 18 in August, when high values of total seston $\left(1433 \mathrm{mg} \mathrm{l}^{-1}\right)$, POC $\left(562 \mu \mathrm{g} \mathrm{l}^{-1}\right)$ and chlorophyll $\left(3.7 \mu \mathrm{g} \mathrm{l}^{-1}\right)$ were recorded, but low values of nitrogen $\left(32 \mu \mathrm{g}^{-1}\right)$.

The data collected during this study provide a description of the trophic situation of the lake in the first years after the liming intervention. The changes in the water chemistry have not actually had a profound effect on the trophic state of the lake, which has remained at a medium-low level. The values found for total seston and its components are not in fact very different from those measured in Lake Maggiore at the beginning of the $90 \mathrm{~s}$, when the lake was in a meso-oligotrophic condition (Bertoni \& Callieri 1993). 


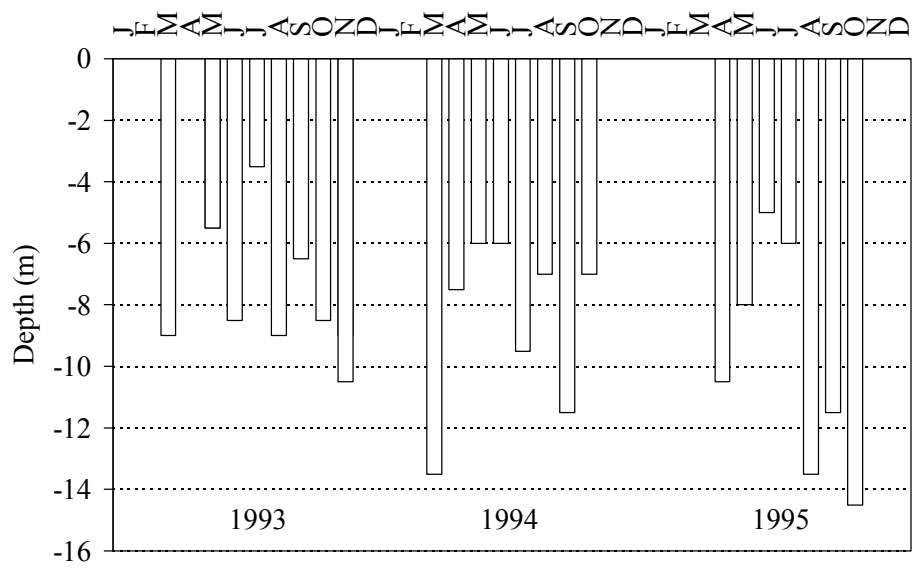

Fig. 2. Secchi disk transparency for period $1993 \div 1995$.
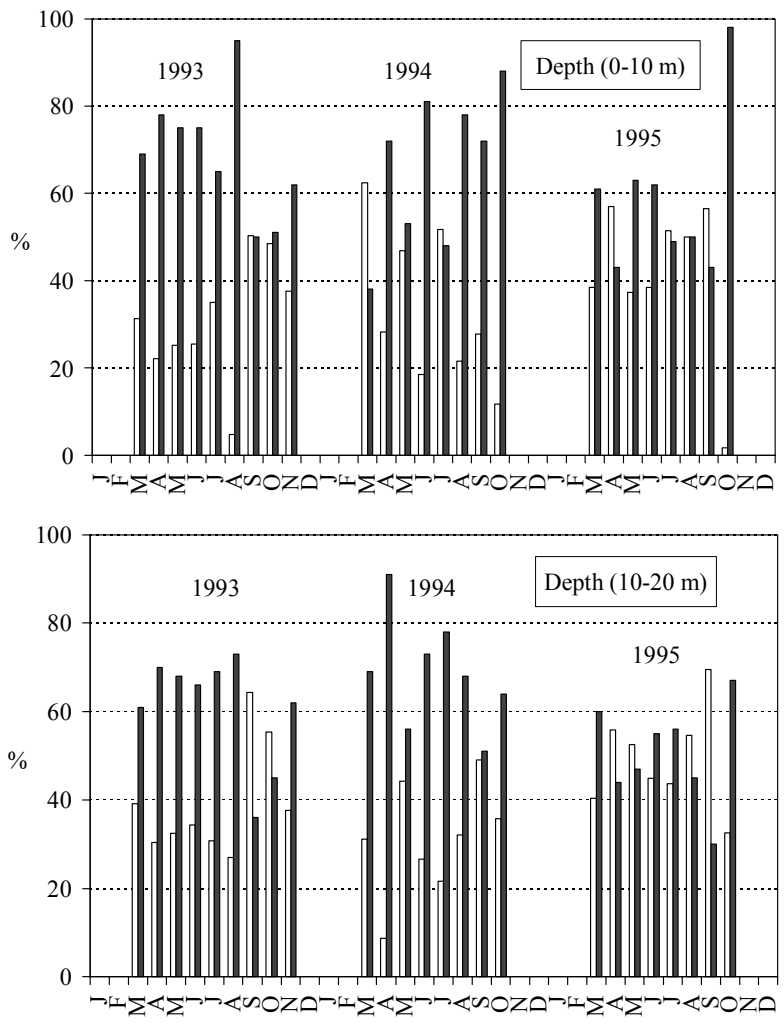

Fig. 3. Monthly variations of percent values of inorganic and organic seston recorded at different depths.

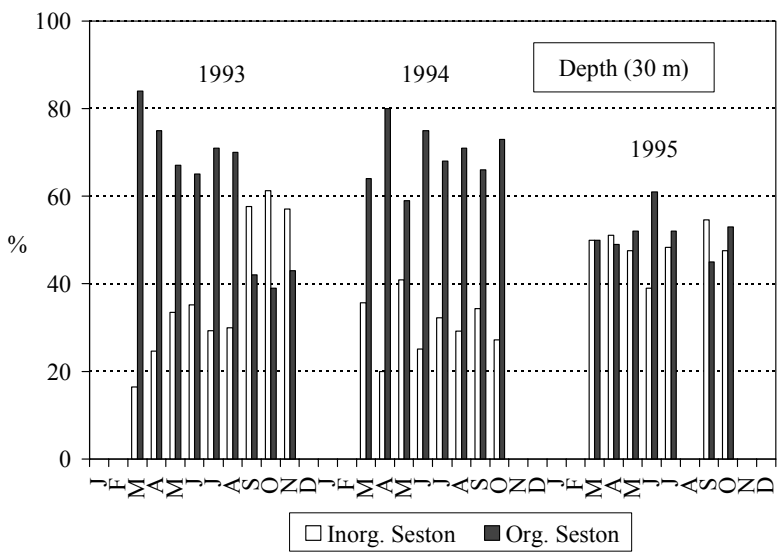


Tab. 3. Seasonal concentrations and annual means of organic carbon and nitrogen, expressed in $\mu \mathrm{g} \mathrm{mg}^{-1}$ of dry weight of sediment, and respective values of $\mathrm{C} / \mathrm{N}$ ratio. Seasonal values and annual means, expressed as unit per gram of organic matter, of chlorophyll derivatives $\left(\mathrm{SPDU}_{665}\right)$, of total carotenoids $(\mathrm{SPDU} 450$ ), and of respective ratio chlorophyll derivatives/total carotenoids (CD/TC).

\begin{tabular}{|c|c|c|c|c|c|c|c|c|c|c|c|c|c|}
\hline & & \multicolumn{6}{|c|}{1993} & \multicolumn{6}{|c|}{1994} \\
\hline & & C org. & $\mathrm{N}$ org. & $\mathrm{C} / \mathrm{N}$ & $\mathrm{SPDU}_{665}$ & $\mathrm{SPDU}_{450}$ & $\mathrm{CD} / \mathrm{TC}$ & C org. & $\mathrm{N}$ org. & $\mathrm{C} / \mathrm{N}$ & $\mathrm{SPDU}_{665}$ & $\mathrm{SPDU}_{450}$ & $\mathrm{CD} / \mathrm{TC}$ \\
\hline \multirow{4}{*}{$\begin{array}{l}\text { St. } 0 \\
(4 \mathrm{~m})\end{array}$} & March & - & - & - & - & - & - & 33.40 & 2.10 & 15.90 & 99.25 & 211.04 & 0.47 \\
\hline & July & 33.30 & 2.20 & 14.90 & 68.46 & 200.29 & 0.34 & 29.20 & 2.60 & 11.40 & 65.85 & 163.75 & 0.40 \\
\hline & November & 37.80 & 2.80 & 13.30 & 133.50 & 255.94 & 0.52 & 33.30 & 2.80 & 11.90 & 69.35 & 161.77 & 0.43 \\
\hline & Annual mean & 35.55 & 2.50 & 14.10 & 100.98 & 228.11 & 0.43 & 32.00 & 2.50 & 13.10 & 78.15 & 178.85 & 0.43 \\
\hline \multirow{4}{*}{$\begin{array}{l}\text { St. 1 } \\
(7 \mathrm{~m})\end{array}$} & March & 79.70 & 6.80 & 11.70 & 199.05 & 331.08 & 0.60 & 33.20 & 2.60 & 12.70 & 192.27 & 302.59 & 0.64 \\
\hline & July & 29.50 & 2.20 & 13.20 & 140.97 & 240.70 & 0.59 & 29.40 & 2.60 & 11.20 & 158.43 & 268.01 & 0.59 \\
\hline & November & 37.30 & 3.40 & 11.10 & 147.06 & 241.74 & 0.61 & 28.50 & 2.50 & 11.50 & 182.43 & 269.45 & 0.68 \\
\hline & Annual mean & 48.83 & 4.13 & 12.00 & 162.36 & 271.17 & 0.60 & 30.40 & 2.60 & 11.80 & 177.71 & 280.02 & 0.63 \\
\hline \multirow{4}{*}{$\begin{array}{l}\text { St. } 2 \\
(15 \mathrm{~m})\end{array}$} & March & 63.10 & 6.00 & 10.50 & 190.00 & 369.01 & 0.52 & 55.00 & 4.60 & 12.00 & 169.50 & 333.48 & 0.51 \\
\hline & July & 67.70 & 6.50 & 10.40 & 200.73 & 374.44 & 0.54 & 50.80 & 5.20 & 9.80 & 166.72 & 339.80 & 0.49 \\
\hline & November & 47.00 & 4.70 & 10.10 & 124.76 & 264.88 & 0.47 & 59.40 & 6.50 & 9.20 & 195.08 & 358.77 & 0.54 \\
\hline & Annual mean & 59.27 & 5.73 & 10.33 & 171.83 & 336.11 & 0.51 & 55.07 & 5.40 & 10.30 & 177.10 & 344.02 & 0.51 \\
\hline \multirow{4}{*}{$\begin{array}{l}\text { St. } 3 \\
(22 \mathrm{~m})\end{array}$} & March & 50.60 & 5.10 & 10.00 & 172.68 & 374.75 & 0.46 & 54.50 & 4.50 & 12.10 & 81.44 & 192.20 & 0.42 \\
\hline & July & 62.10 & 5.80 & 10.70 & 130.19 & 289.73 & 0.45 & 44.20 & 5.00 & 8.90 & 74.02 & 181.52 & 0.41 \\
\hline & November & 57.60 & 5.90 & 9.80 & 116.59 & 256.28 & 0.46 & 45.40 & 5.10 & 8.80 & 74.78 & 182.58 & 0.41 \\
\hline & Annual mean & 56.77 & 5.60 & 10.17 & 139.82 & 306.92 & 0.46 & 48.03 & 4.90 & 9.90 & 76.75 & 185.43 & 0.41 \\
\hline \multirow{4}{*}{$\begin{array}{l}\text { St. } 4 \\
(28 \mathrm{~m})\end{array}$} & March & 64.20 & 6.50 & 9.90 & 77.00 & 208.21 & 0.37 & - & - & - & 38.28 & 121.19 & 0.32 \\
\hline & July & 49.60 & 4.50 & 10.90 & 68.11 & 196.78 & 0.35 & 47.30 & 5.10 & 9.30 & 75.95 & 188.01 & 0.42 \\
\hline & November & 64.20 & 6.10 & 10.50 & 78.67 & 204.53 & 0.39 & 46.40 & 5.20 & 8.90 & 53.24 & 154.45 & 0.35 \\
\hline & Annual mean & 59.33 & 5.70 & 10.43 & 74.60 & 203.17 & 0.37 & 46.90 & 5.20 & 9.10 & 55.82 & 154.55 & 0.36 \\
\hline \multirow{4}{*}{$\begin{array}{l}\text { St. } 5 \\
(35 \mathrm{~m})\end{array}$} & March & 53.30 & 5.00 & 10.60 & 87.22 & 255.92 & 0.34 & 47.00 & 4.50 & 10.40 & 44.66 & 139.21 & 0.32 \\
\hline & July & 47.00 & 4.60 & 10.30 & 47.80 & 142.58 & 0.34 & 49.50 & 5.00 & 9.80 & 83.23 & 256.87 & 0.32 \\
\hline & November & 46.30 & 4.40 & 10.50 & 22.53 & 126.16 & 0.18 & 42.80 & 4.30 & 10.10 & 38.12 & 128.01 & 0.30 \\
\hline & Annual mean & 48.87 & 4.67 & 10.47 & 52.52 & 174.89 & 0.29 & 46.40 & 4.60 & 10.10 & 55.34 & 174.70 & 0.31 \\
\hline
\end{tabular}

The rather low trophic state of the lake between 1993 and 1995 is largely due to the quite low phosphorus concentrations in water after the liming (Calderoni \& Tartari 2001). However, the lake's trophic state is expected to increase in the future with the evolution of the water chemistry, and the high phosphorus loads which continue to arrive from the catchment area, especially from diffused sources (Calderoni et al. 1997).

\subsection{Parameters of the sediments}

There were no major variations in the distribution in space of the parameters considered over the two years of the study (1993-94).

\subsubsection{Calcium carbonate}

The calcium carbonate concentrations were generally not particularly high, and reflect the lithological composition of the watershed, which is made up mostly of siliceous rocks (Boriani \& Sacchi 1974). During the two years of the study, calcium carbonate contents on average between 2.9 and $4 \%$ were estimated, with slight variations along the bathymetric profile, where values higher than $4 \%$ were estimated especially in spring and autumn (Fig. 4).

The observed values show clearly that, at least in the early stages following the liming, there was no significant increase in carbonate concentrations at sediment level. This confirms findings in other limed lake environments (Driscoll et al. 1989). As regards Lake Orta, it was calculated that around $85 \%$ of the calcium carbonate added to the lake dissolved during the early stages of the intervention, with a consequent increase in concentrations of calcium ion in the water column which reached values of around $13 \mathrm{mg} \mathrm{l}^{-1}$ in 1993-94 (Calderoni et al. 1993).

\subsubsection{Organic matter, organic carbon and nitrogen and plant pigments}

The highest mean concentrations of organic matter (between 13 and 14\%), organic carbon (between 5 and $6 \%$ ) and organic nitrogen (between 0.5 and $0.6 \%$ ) were observed between 15 and $35 \mathrm{~m}$. Variable values were found during the year between 15 and $28 \mathrm{~m}$, where in 1993 the contents of organic matter and carbon were on average higher than those of 1994 (Fig. 4 and Tab. 3). In contrast, organic nitrogen concentrations were less variable in space and time in the whole of the sub-littoral and profound layer (between 15 and $35 \mathrm{~m}$ ).

In spring 1993, high contents of organic matter $(16.2 \%)$, organic carbon $(8 \%)$ and nitrogen $(0.7 \%)$ were also estimated in the littoral layer $(7 \mathrm{~m})$; however, during the year, lower concentrations were recorded in this layer than in the underlying layers. Interestingly, the seasonal variations in the contents of these parameters along the bathymetric profile are linked to the different 
1993
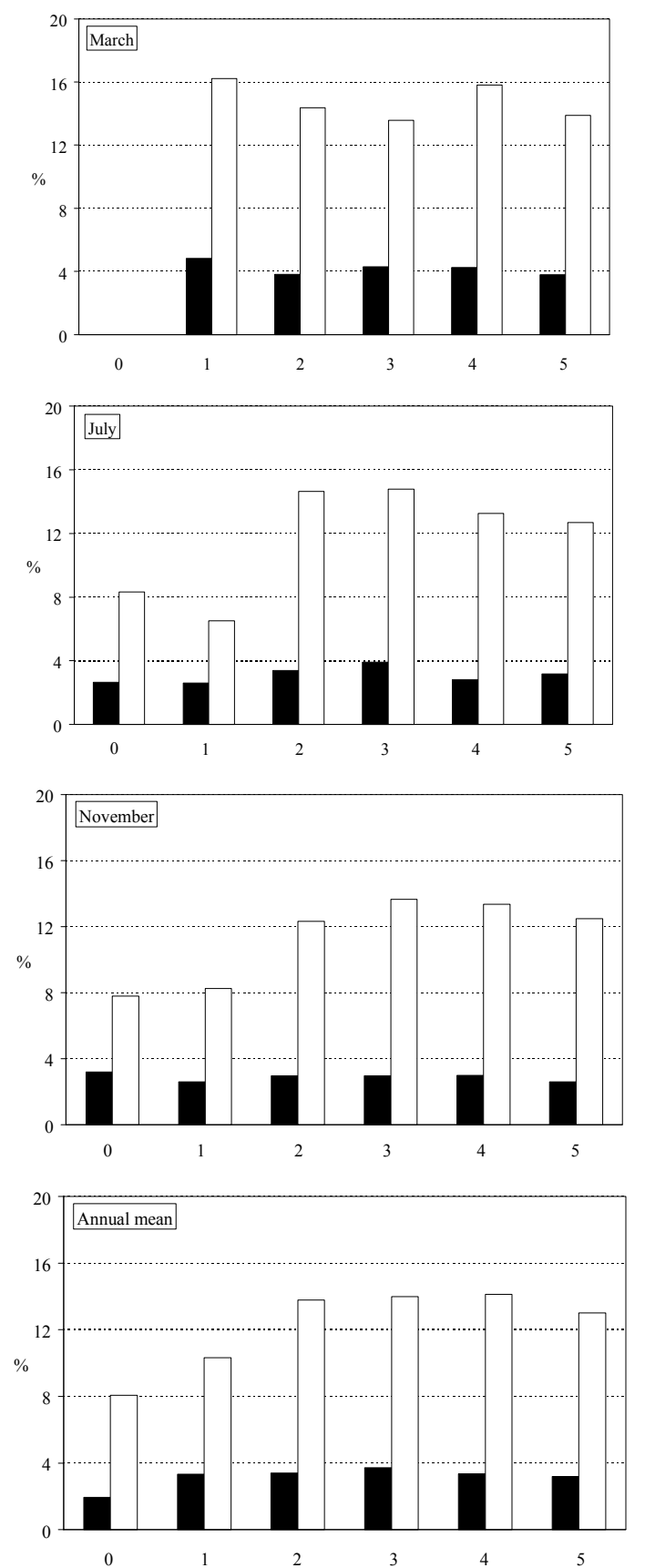

1994
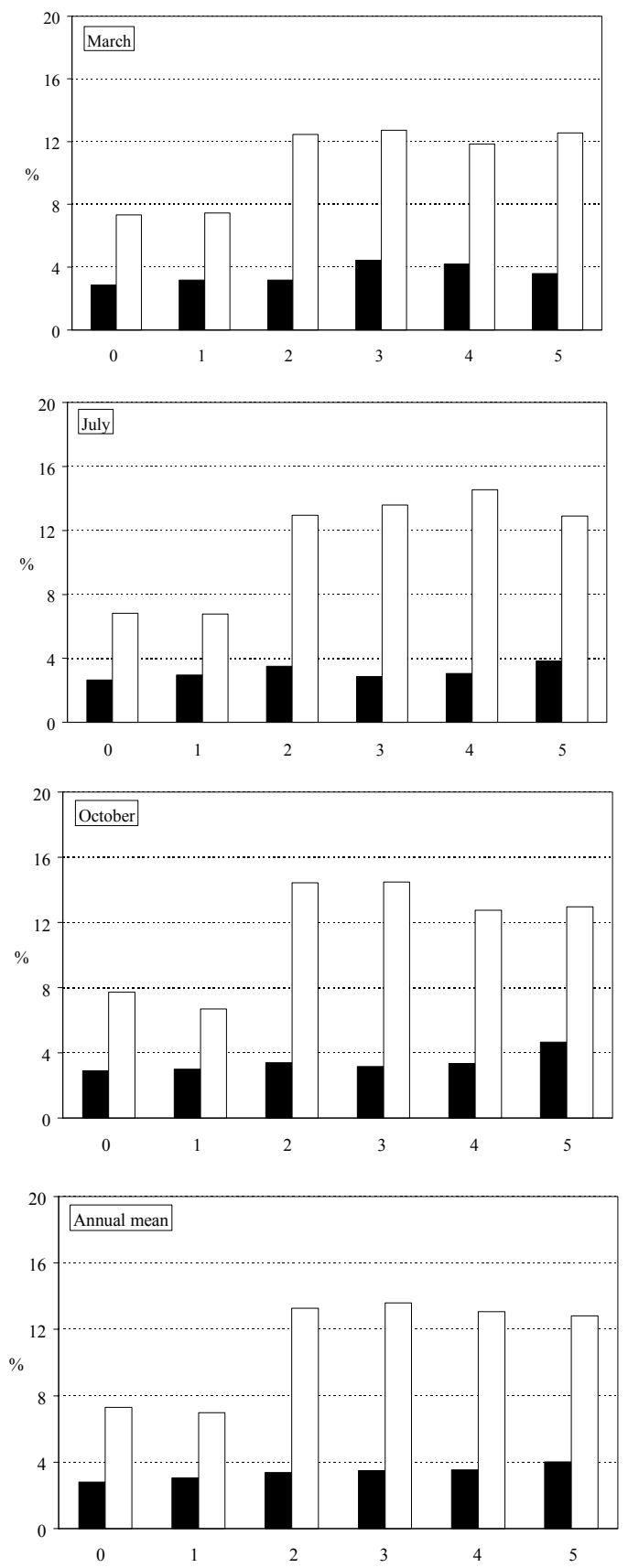

$\square_{\mathrm{CaCO} 3} \square$ organic matter

Fig. 4. Seasonal concentrations and annual means, expressed as percentage of dry weight of sediment, of carbonates $\left(\mathrm{CaCO}_{3}\right)$, and organic matter at the different stations considered in 1993-1994.

contribution of the organic matter reaching the sediment. In fact, the concentrations of inorganic carbon and nitrogen along the whole bathymetric profile were extremely low during the whole year, with values of zero or close to zero.

Between 15 and $35 \mathrm{~m}$ the autochthonous component, especially that of plant origin, was well represented in the organic matter of the sediment. The $\mathrm{C} / \mathrm{N}$ ratio pre- sented values on average between 9 and 10, with little variation during the year. Higher values of the ratio (between 12 and 14) were estimated in the littoral layers (4 and $7 \mathrm{~m}$ ), where, along with the autochthonous component, there is probably a significant contribution of allochthonous matter from the shore environment, especially at certain times of year (Wetzel 1975; Håkanson \& Jansson 1983). 
Information on the qualitative composition of the sedimented organic matter is also provided by the distribution in space of plant pigment concentrations; these show significant seasonal variations with depth, reflecting the temporal dynamics of their deposition and degradation at sediment level.

Both in 1993 and 1994, higher mean contents were recorded between depths of 7 and $15 \mathrm{~m}$, with a maximum of 178 for chlorophyll derivatives and 344 for carotenoids. Lower values, especially for the chlorophyll derivatives, were recorded between 28 and $35 \mathrm{~m}$ (Tab. $3)$. In this depth interval values of the $\mathrm{CD} / \mathrm{CT}$ ratio were measured between 0.2 and 0.4 , confirming the importance of the autochthonous component, especially of phytoplankton, in the organic matter of the sediment (Sanger \& Gorham 1970; Wetzel 1970; Gorham \& Sanger 1975; Swain 1985).

The presence of plant pigments of largely autochthonous origin was also revealed by paleo-limnological studies carried out in the deep zone of the lake by Guilizzoni \& Lami (1990) in the years prior to the liming. The accumulation of these pigments in the sediment was probably caused by an increase in algal production following the removal of the ammoniacal nitrogen and copper loads by the Bemberg factory from the $80 \mathrm{~s}$, and also to the high acidity of the water, which facilitated the preservation of the pigments at bottom level. Nevertheless, the high carotenoid content seems to suggest that the autochthonous component (algae and macrophytes) is also important in the sediment of the shallower layers (between 4 and $22 \mathrm{~m}$ ), where higher values (on average between 0.4 and 0.6 ), of the $\mathrm{CD} / \mathrm{CT}$ ratio were recorded. However, even higher values (between 0.6 and 0.7 ) were measured at the depth of $7 \mathrm{~m}$, where a greater quantity of allochthonous material of plant origin arrives from the shore.

\subsection{Macrobenthic fauna}

In the two years of study the stations along the transect considered showed a qualitatively rather poor macrobenthic community composed mainly of Oligochaeta and Diptera Chironomidae. The other groups of organisms found, such as Turbellaria, Hydracarina, and some Insecta orders (Diptera Ceratopogonidae, Trichoptera, Megaloptera), were poorly represented. The most numerous populations were observed between 4 and $22 \mathrm{~m}$, where mean densities varying from 1030 to 6258 ind $\mathrm{m}^{-}$ ${ }^{2}$ were recorded (Tabs 4 and 5).

The Oligochaeta (Figs 5 and 6), comprising some species of Naididae and Tubificidae, were present in higher densities in the littoral layers (4 and $7 \mathrm{~m}$ ), with values varying over the year from 400 to 2177 ind $\mathrm{m}^{-2}$, correlated to the presence of young and mature individuals of Limnodrilus hoffmeisteri, which dominated the population numerically. The Oligochaeta were in contrast very scarce at $15 \mathrm{~m}$, and in the underlying layers the quali- and quantitative structure of the popula- tion showed some major differences in the two years of the study.

In 1993, not negligible densities of Naididae particularly of Veidovskiella comata e Nais communis, were found at $22 \mathrm{~m}$, where the Tubificidae were absent. In contrast, the Tubificidae were present in significant numbers between 28 and $35 \mathrm{~m}$, where they were the dominant element of the macrobenthos due to the numbers of young and mature individuals of Tubifex tubifex. In 1994 Oligochaeta were not recorded at $22 \mathrm{~m}$, and in the underlying layers the density of Tubifex tubifex, the dominant element of the population, was lower than was recorded in 1993.

The Chironomidae were made up of immature individuals (larvae and pupae) belonging to the sub-families of the Tanypodinae, Orthocladiinae and Chironominae.

During the year their density was fairly high in the top $22 \mathrm{~m}$, where they made up over $60 \%$ of the total density, due especially to the contribution of the genera Procladius e Chironomus thummi gr., both of which were present in low numbers at greater depths. Parakiefferiella bathophila e Dicrotendipes nervosus gr. had some quantitative importance in the littoral layers (4 and $7 \mathrm{~m}$ ). In 1994, due to the marked decrease in numbers of the Oligochaeta, the Chironomidae were, along with the genus Zavrelimyia, the dominant element of the macrobenthos also at a depth of $28 \mathrm{~m}$.

The other groups are of little importance in the total density of the benthos, with percentages between 1 and $9 \%$. Numerically the most significant are the Trichoptera, particularly Mystacides azurea and the Ceratopogonidae, which are present mainly in the shallower layers. In 1994 the Turbellaria were of some importance between 22 and $28 \mathrm{~m}$.

The trend of benthic biomass at the sampling stations generally reflects the trend of the densities (Tabs 4 and 5). High biomass values were observed in the top $22 \mathrm{~m}$, due largely to the contribution of the Diptera Chironomidae, which on average represent over $50 \%$ of the total biomass. In this depth interval the biomass values of the Chironomidae vary over the years in relation to the biological cycle of the elements which are numerically best represented (Procladius e Chironomus thummi gr.). The biomass of the Chironomidae (Figs 5 and 6), which is high in spring, tends to decrease during summer and autumn as the mature larvae emerge and the young larvae of the new generation, smaller and with a low mean individual weight, increase.

In the littoral layers (4 and $7 \mathrm{~m}$ ), the Oligochaeta too represent a significant component of the total biomass, largely due to the contribution of young and mature individuals of Limnodrilus hoffmeisteri and of Branchiura sowerbyi. At certain moments in the season Branchiura sowerbyi, which represents quite a small part of the population in numerical terms, may have a major impact on the benthic biomass because of the greater mean weight of the individuals. 
Tab. 4. Annual mean values for density and biomass, recorded in 1993, for different taxonomic entities in the various stations. Values relating to Chironomidae include larvae and pupae. Percentages are also presented.

\begin{tabular}{|c|c|c|c|c|c|c|c|c|c|c|c|c|}
\hline \multirow[b]{2}{*}{ Depth (m) } & \multicolumn{6}{|c|}{ Density (ind. $\mathrm{m}^{-2}$ ) } & \multicolumn{6}{|c|}{$\operatorname{Biomass}\left(\mathrm{mg} \mathrm{m}^{-2}\right)$} \\
\hline & $\begin{array}{l}\text { St. } 0 \\
(4 \mathrm{~m})\end{array}$ & $\begin{array}{l}\text { St. } 1 \\
(7 \mathrm{~m})\end{array}$ & $\begin{array}{l}\text { St. } 2 \\
(15 \mathrm{~m})\end{array}$ & $\begin{array}{l}\text { St. 3 } \\
(22 \mathrm{~m})\end{array}$ & $\begin{array}{l}\text { St. } 4 \\
(28 \mathrm{~m})\end{array}$ & $\begin{array}{l}\text { St. } 5 \\
(35 \mathrm{~m})\end{array}$ & $\begin{array}{l}\text { St. } 0 \\
(4 \mathrm{~m})\end{array}$ & $\begin{array}{l}\text { St. } 1 \\
(7 \mathrm{~m})\end{array}$ & $\begin{array}{l}\text { St. } 2 \\
(15 \mathrm{~m})\end{array}$ & $\begin{array}{l}\text { St. } 3 \\
(22 \mathrm{~m})\end{array}$ & $\begin{array}{l}\text { St. } 4 \\
(28 \mathrm{~m})\end{array}$ & $\begin{array}{l}\text { St. } 5 \\
(35 \mathrm{~m})\end{array}$ \\
\hline \multicolumn{13}{|l|}{ OLIGOCHAETA } \\
\hline $\begin{array}{l}\text { NAIDIDAE } \\
\text { Chaetogaster }\end{array}$ & - & - & - & 24 & 8 & 4 & - & - & - & 5 & 1 & 1 \\
\hline Pristina longiseta & 60 & - & - & - & - & - & 1 & - & - & - & - & - \\
\hline Vejdovskiella comata & - & - & - & 250 & 52 & - & - & - & - & 10 & 2 & - \\
\hline Nais communis & - & - & 28 & 174 & 52 & 8 & - & - & 2 & 11 & 4 & 0 \\
\hline Nais elinguis & - & - & 8 & - & - & - & - & - & 0 & - & - & - \\
\hline TUBIFICIDAE & & - & - & - & - & - & - & - & - & - & - & - \\
\hline Bothrioneurum vejdovskianum & 24 & - & - & - & - & - & 3 & - & - & - & - & - \\
\hline Branchiura sowerbyi & 18 & 56 & - & - & - & - & 21 & 2674 & - & - & - & - \\
\hline Tubifex tubifex & - & & - & - & 222 & 28 & - & - & - & - & 1337 & 123 \\
\hline immature Tubificidae & 6 & 75 & - & - & 250 & 508 & 5 & 20 & - & - & 561 & 718 \\
\hline Limnodrilus hoffmeisteri & 2059 & 186 & 4 & - & 12 & 4 & 1105 & 70 & 1 & - & 6 & 44 \\
\hline immature Limnodrilus & - & 321 & - & - & - & - & - & 66 & - & - & - & - \\
\hline Oligochaeta total & 2167 & 638 & 40 & 448 & 596 & 552 & 1135 & 2830 & 3 & 26 & 1911 & 886 \\
\hline$\%$ & 35 & 21 & 3 & 28 & 85 & 79 & 33 & 48 & 0 & 1 & 82 & 79 \\
\hline \multicolumn{13}{|l|}{ HYDRACARINA } \\
\hline PIONIDAE & - & - & - & - & - & 4 & - & - & - & - & - & 52 \\
\hline Hydracarina total & - & - & - & - & - & 4 & - & - & - & - & - & 52 \\
\hline$\%$ & - & - & - & - & - & 1 & - & - & - & - & - & 5 \\
\hline $\begin{array}{l}\text { INSECTA } \\
\text { Diptera } \\
\text { CHIRONOMIDAE } \\
\text { Tanypodinae }\end{array}$ & & & & & & & & & & & & \\
\hline Procladius & 1065 & 1376 & 547 & 210 & 8 & 24 & 541 & 1238 & 1074 & 489 & 26 & 28 \\
\hline Macropelopia & - & - & - & 4 & 4 & 4 & - & - & - & 14 & 3 & 4 \\
\hline Ablabesmyia & 149 & 87 & 99 & - & - & 4 & 12 & 11 & 30 & - & - & 5 \\
\hline Zavrelimyia & 6 & 12 & 135 & 143 & 32 & 91 & 1 & 2 & 33 & 95 & 17 & 41 \\
\hline \multicolumn{13}{|l|}{ Orthocladiinae } \\
\hline Paracladius & 48 & - & - & - & - & - & 4 & - & - & - & - & - \\
\hline Cricotopus (Isocladius) & 36 & - & - & - & - & - & 3 & - & - & - & - & - \\
\hline Cricotopus (Cricotopus) & - & 4 & - & - & - & - & - & 0 & - & - & - & - \\
\hline \multicolumn{13}{|l|}{ Chironominae } \\
\hline Pagastiella orophila & - & 4 & - & - & - & - & - & 0 & - & - & - & - \\
\hline Phaenopsectra & 137 & 8 & - & 4 & 4 & - & 19 & 0 & - & 4 & 5 & - \\
\hline Chironomus thummi gr. & 625 & 460 & 436 & 801 & 55 & 16 & 1234 & 1686 & 1174 & 4067 & 375 & 112 \\
\hline Polypedilum nubeculosum gr. & 78 & 36 & - & - & - & - & 23 & 18 & - & - & - & - \\
\hline Dicrotendipes nervosus gr. & 1678 & 75 & - & - & - & - & 465 & 16 & - & - & - & - \\
\hline Demicryptochironomus & 6 & - & - & - & - & - & 1 & - & - & - & - & - \\
\hline Cladopelma lateralis gr. & - & 8 & - & - & - & - & - & 1 & - & - & - & - \\
\hline Chironomidae total & 3882 & 2367 & 1221 & 1162 & 103 & 139 & 2307 & 2999 & 2311 & 4669 & 426 & 190 \\
\hline$\%$ & 62 & 77 & 97 & 72 & 15 & 20 & 66 & 51 & 90 & 99 & 18 & 17 \\
\hline $\begin{array}{l}\text { CERATOPOGONIDAE } \\
\text { Megaloptera }\end{array}$ & 54 & 16 & - & - & - & - & 11 & 5 & - & - & - & - \\
\hline Sialis & - & - & 4 & - & - & - & - & - & 259 & - & - & - \\
\hline $\begin{array}{l}\text { Trichoptera } \\
\text { Ecnomus tenellus }\end{array}$ & & & & & & & & & & & & \\
\hline Ecnomus tenellus & - & 8 & - & - & - & - & - & 3 & - & - & - & - \\
\hline Mystacides azurea & 155 & 48 & - & - & - & - & 27 & 28 & - & - & - & - \\
\hline Other insecta total & 209 & 72 & 4 & - & - & - & 38 & 36 & 259 & - & - & - \\
\hline$\%$ & 3 & 2 & 0 & - & - & - & 1 & 1 & 10 & - & - & - \\
\hline GENERAL TOTAL & 6258 & 3077 & 1265 & 1610 & 699 & 695 & 3480 & 5865 & 2573 & 4695 & 2337 & 1128 \\
\hline
\end{tabular}

The values of the Oligochaeta biomass were very low between 15 and $22 \mathrm{~m}$, where they were very scarce or represented by Naididae, which are small in size. In contrast, in the underlying layers (28 and $35 \mathrm{~m}$ ) Tubifex tubifex represented almost the entire macrobenthos, also in terms of biomass, especially in 1993. In 1994, at 28 $\mathrm{m}$, the Chironomidae with the genus Zavrelimyia were dominant, although their density values were not high.
The participation of the other groups of organisms in terms of biomass is not very different from their participation in terms of density, and represents between 1 and $10 \%$ of the macrobenthos. The commonest elements numerically play a significant role, especially Mystacides azurea among the Trichoptera and the Ceratopogonidae at 4 and $7 \mathrm{~m}$, and the Turbellaria at 22 and $28 \mathrm{~m}$. 
Tab. 5. Annual mean values for density and biomass, recorded in 1994, for different taxonomic entities in the various stations. Values relating to Chironomidae include larvae and pupae. Percentages are also presented.

\begin{tabular}{|c|c|c|c|c|c|c|c|c|c|c|c|c|}
\hline \multirow[b]{2}{*}{ Depth (m) } & \multicolumn{6}{|c|}{ Density (ind. $\mathrm{m}^{-2}$ ) } & \multicolumn{6}{|c|}{ Biomass $\left(\mathrm{mg} \mathrm{m}^{-2}\right)$} \\
\hline & $\begin{array}{l}\text { St. } 0 \\
(4 \mathrm{~m})\end{array}$ & $\begin{array}{l}\text { St. } 1 \\
(7 \mathrm{~m})\end{array}$ & $\begin{array}{l}\text { St. } 2 \\
(15 \mathrm{~m})\end{array}$ & $\begin{array}{l}\text { St. 3 } \\
(22 \mathrm{~m})\end{array}$ & $\begin{array}{l}\text { St. } 4 \\
(28 \mathrm{~m})\end{array}$ & $\begin{array}{l}\text { St. } 5 \\
(35 \mathrm{~m})\end{array}$ & $\begin{array}{l}\text { St. } 0 \\
(4 \mathrm{~m})\end{array}$ & $\begin{array}{l}\text { St. } 1 \\
(7 \mathrm{~m})\end{array}$ & $\begin{array}{l}\text { St. } 2 \\
(15 \mathrm{~m})\end{array}$ & $\begin{array}{l}\text { St. } 3 \\
(22 \mathrm{~m})\end{array}$ & $\begin{array}{l}\text { St. } 4 \\
(28 \mathrm{~m})\end{array}$ & $\begin{array}{l}\text { St. } 5 \\
(35 \mathrm{~m})\end{array}$ \\
\hline \multicolumn{13}{|l|}{ TURBELLARIA } \\
\hline Polycelis nigra & - & - & 4 & 40 & 12 & 4 & - & - & 3 & 51 & 23 & 5 \\
\hline Turbellaria total & - & - & 4 & 40 & 12 & 4 & - & - & 3 & 51 & 23 & 5 \\
\hline$\%$ & - & - & 0 & 4 & 6 & 2 & - & - & 0 & 1 & 9 & 1 \\
\hline \multicolumn{13}{|l|}{$\begin{array}{l}\text { OLIGOCHAETA } \\
\text { NAIDIDAE }\end{array}$} \\
\hline Dero digitata & - & - & 4 & - & 4 & - & - & - & 1 & - & 2 & - \\
\hline Nais commumis & - & - & 4 & - & - & - & - & - & 0 & - & - & - \\
\hline Naididae others & - & 4 & 4 & - & - & - & - & 0 & 0 & - & - & - \\
\hline TUBIFICIDAE & & & & & & & & & & & & \\
\hline Branchiura sowerbyi & 270 & 24 & - & - & - & - & 9104 & 37 & - & - & - & - \\
\hline Tubifex tubifex & - & - & - & - & 4 & - & - & - & - & - & 10 & - \\
\hline immature Tubificidae & - & 12 & - & - & 32 & 159 & - & 1 & - & - & 34 & 542 \\
\hline Limnodrilus hoffmeisteri & 226 & 36 & - & - & - & - & 788 & 52 & - & - & - & - \\
\hline immature Limnodrilus & 1015 & 825 & 12 & - & - & - & 634 & 358 & 3 & - & - & - \\
\hline Oligochaeta total & 1511 & 901 & 24 & - & 40 & 159 & 10526 & 448 & 4 & - & 46 & 542 \\
\hline$\%$ & 35 & 26 & 2 & - & 19 & 89 & 74 & 9 & 0 & - & 19 & 92 \\
\hline $\begin{array}{l}\text { INSECTA } \\
\text { Diptera } \\
\text { CHIRONOMIDAE } \\
\text { Tanypodinae }\end{array}$ & & & & & & & & & & & & \\
\hline Procladius & 817 & 964 & 769 & 190 & 4 & - & 505 & 1108 & 994 & 333 & 2 & - \\
\hline Macropelopia & - & - & - & - & 4 & 4 & - & - & - & - & 30 & 39 \\
\hline Ablabesmyia & 8 & 43 & 4 & 12 & - & - & 3 & 15 & 0 & 1 & - & - \\
\hline Zavrelimyia & 48 & 8 & 48 & 191 & 143 & 8 & 7 & 1 & 45 & 138 & 115 & 2 \\
\hline \multicolumn{13}{|l|}{ Orthocladiinae } \\
\hline Psectrocladius sordidellus gr. & 12 & - & - & - & - & - & 4 & - & - & - & - & - \\
\hline Cricotopus (Isocladius) & - & 4 & - & - & - & - & - & 3 & - & - & - & - \\
\hline $\begin{array}{l}\text { Parakiefferiella bathophila } \\
\text { Chironominae }\end{array}$ & 369 & 440 & 8 & - & - & - & 39 & 68 & 1 & - & - & - \\
\hline Paratendipes & 4 & - & - & - & - & - & 0 & - & - & - & - & - \\
\hline Phaenopsectra & 24 & 44 & - & - & - & 4 & 15 & 18 & - & - & - & 1 \\
\hline Chironomus thummi gr. & 936 & 607 & 563 & 599 & 4 & - & 2741 & 2892 & 2117 & 4237 & 28 & - \\
\hline Polypedilum nubeculosum gr. & 159 & 72 & 4 & - & - & - & 173 & 83 & 2 & - & - & - \\
\hline Dicrotendipes nervosus gr. & 317 & 266 & 8 & - & - & - & 143 & 90 & 1 & - & - & - \\
\hline Demicryptochironomus & 8 & - & - & - & - & - & 2 & - & - & - & - & - \\
\hline Cladopelma lateralis gr. & 16 & 60 & - & - & - & - & 3 & 2 & - & - & - & - \\
\hline Paracladopelma camptolabis gr. & - & 4 & 12 & - & - & - & - & 0 & 3 & - & - & - \\
\hline Tanytarsus & 8 & - & 4 & - & - & - & 1 & - & 4 & - & - & - \\
\hline Chironomidae total & 2726 & 2512 & 1420 & 992 & 155 & 16 & 3636 & 4280 & 3167 & 4709 & 175 & 42 \\
\hline$\%$ & 64 & 73 & 98 & 96 & 75 & 9 & 26 & 90 & 100 & 99 & 72 & 7 \\
\hline $\begin{array}{l}\text { CERATOPOGONIDAE } \\
\text { Trichoptera }\end{array}$ & 32 & 32 & - & - & - & - & 9 & 10 & - & - & - & - \\
\hline Ecnomus tenellus & - & 4 & - & - & - & - & - & 11 & - & - & - & - \\
\hline Mystacides azurea & 8 & 4 & 4 & - & - & - & 9 & 2 & 5 & - & - & - \\
\hline Other insecta total & 40 & 40 & 4 & - & - & - & 18 & 23 & 5 & - & - & - \\
\hline$\%$ & 1 & 1 & 0 & - & - & - & 0 & 1 & 0 & - & - & - \\
\hline GENERAL TOTAL & 4277 & 3453 & 1452 & 1032 & 207 & 179 & 14180 & 4751 & 3179 & 4760 & 244 & 589 \\
\hline
\end{tabular}



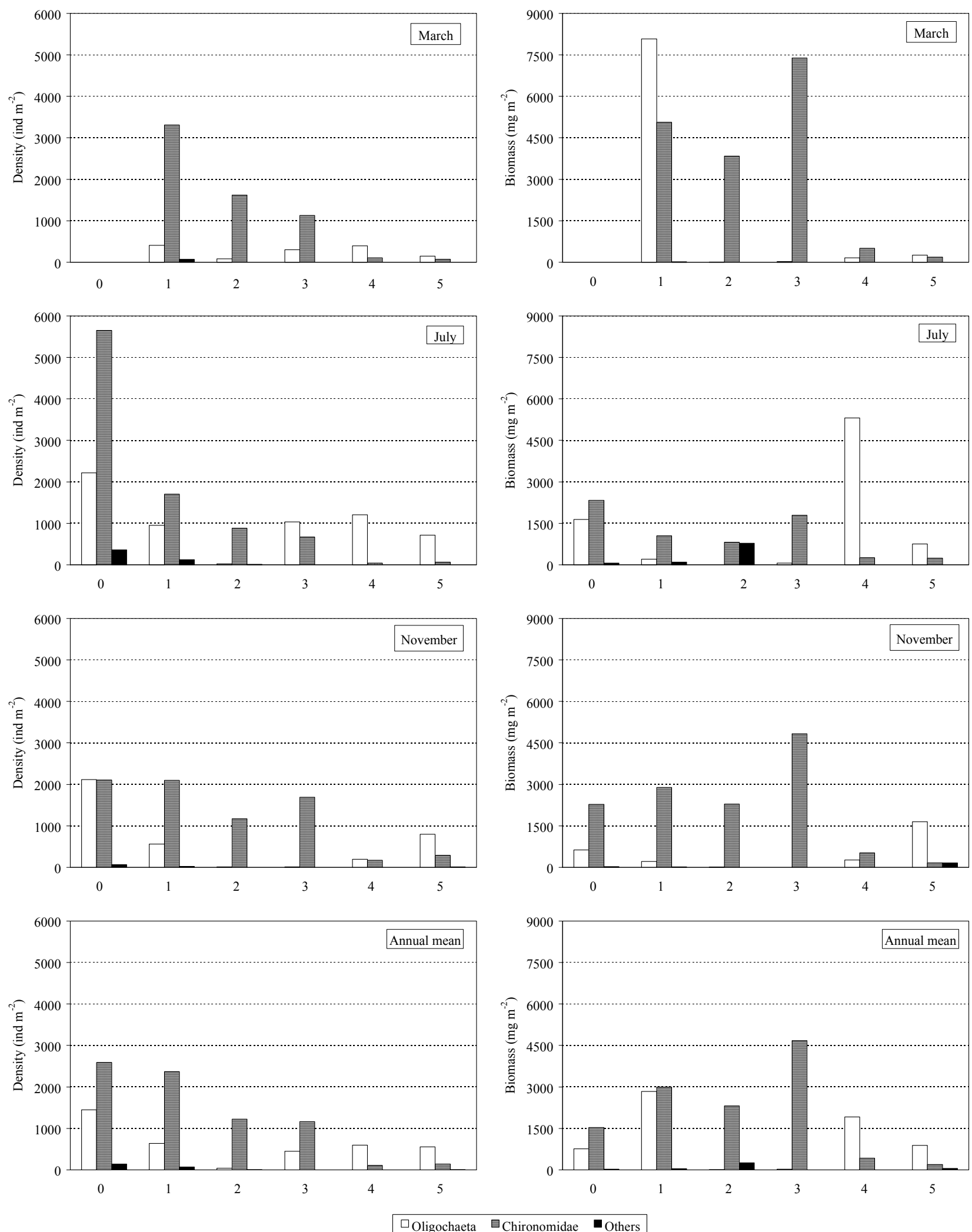

Fig. 5. Seasonal variations and annual means of density and biomass for Oligochaeta, Diptera Chironomidae and other organisms in the different stations considered in 1993. 

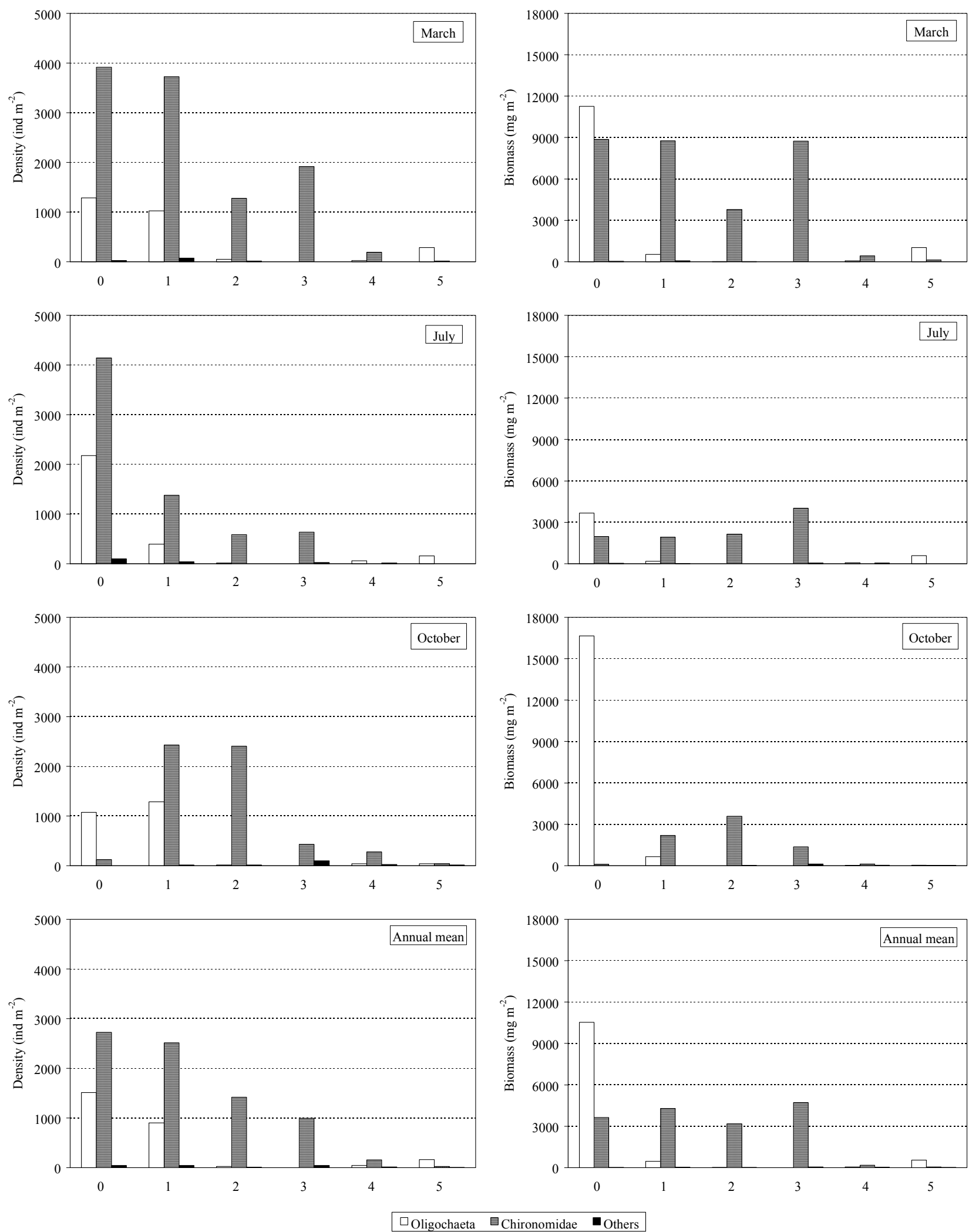

Fig. 6. Seasonal variations and annual means of density and biomass for Oligochaeta, Diptera Chironomidae and other organisms in the different stations considered in 1994. 


\section{CONCLUSIONS}

The results of this investigation seem to indicate that liming the lake has facilitated the repopulation of the Buccione Basin by macrobenthic fauna, at least in numerical terms. As has been observed in other acidified lakes which have undergone neutralisation treatments (Eriksson et al. 1983; Raddum et al. 1986; Keller et al. 1990; Kelly 1991), this basin was colonised initially by some groups of organisms such as Oligochaeta and Diptera Chironomidae, which showed richer populations in the littoral layers.

The qualitative reconstruction of the macrobenthos has however been slower than that of other biological communities such as phyto- and zooplankton, which began to reorganise rapidly in the earliest stages of the lake's recovery (Morabito et al. 2001; Bonacina \& Pasteris 2001). In fact, in 1993-94, around three years after liming, the Oligochaeta community in the Buccione Basin was still made up only of a few Naididae and Tubificidae species varying in their distribution according to depth. Tubificidae species typical of non-acidified lakes, such as Spirosperma ferox, which were present in Lake Orta before it was polluted, were still absent (Bonacina et al. 1986).

The bathymetric distribution of the two most numerous Tubificidae species, Limnodrilus hoffmeisteri and Tubifex tubifex, is especially noteworthy. The former has greatly increased in numbers in the littoral zone, where, being sensitive to acidification (Wiederholm \& Eriksson 1977; Merilainen \& Hynynen 1990), the Tubificidae were poorly represented in the years prior to the liming (Oioli 1969), while the latter mainly colonised the deep layers. It should also be remembered that up to 1996-97 Tubifex tubifex comprised almost all the macrobenthos in the entire deep zone of the lake (Baudo et al. 2001), where it was already present at the beginning of the 80 s when the lake was strongly acidified (Bonacina \& Bonomi 1984).

The different bathymetric distribution of the two species of Tubificidae is dependent on a set of factors among which those linked to the chemical-physical characteristics of the sediments and the depth undoubtedly play a major role (Nalepa \& Thomas 1976; Barton 1988; Mc Murtry et al. 1983). Both species prefer a substrate made up of silt and sand, but while Limnodrilus hoffmeisteri in lakes normally colonises the littoral and sub-littoral layers, Tubifex tubifex has a preference for the deep zone, thanks to its ability to reproduce and increase even at temperatures below $10{ }^{\circ} \mathrm{C}$ and to survive for long periods at low oxygen concentrations (Milbrink 1980; Hoffmann et al. 1986; Anlauf \& Neumann 1997).

Furthermore, Tubifex tubifex is a species which can adapt to environments with different degrees of trophy and pollution, and it is undoubtedly more tolerant of acidification than other Tubificidae species (Wiederholm \& Dave 1989; Johnson et al. 1992). In Lake Orta it has also shown great resistance to the high content of heavy metal in the sediment, particularly copper, chrome, zinc and nickel; in the past this derived from industrial waste, and since the liming it has gone on increasing, especially in the upper layers, with the precipitation of these elements from the water column (Baudo \& Beltrami 2001). The high degree of ecological adaptability of Tubifex tubifex is undoubtedly helped by its genetic variability: within the species, in fact, various ecological races correlated with different environmental conditions have been identified (Anlauf \& Neumann 1997).

The Diptera Chironomidae community is still also rather poor in quality. After the liming, some larval forms of Orthocladiinae in particular increased in number, especially Parakiefferiella bathophila and some genera of Tanypodinae (Procladius and Ablabesmyia) and Chironominae (Dicrotendipes and Chironomus thummi gr.), which were already present in the littoral zone of the lake during its phases of pollution. The number of larval forms found along the transect examined is still markedly lower than the number which would normally characterise this type of community in natural lake environments. The Tanytarsini, for instance, found at depths above $4 \mathrm{~m}$ are still very scarce (De Margaritis 1995); they were well represented before the lake was polluted, as is shown by the analysis of a sediment core taken in the Buccione Basin in 1993 at a depth of $22 \mathrm{~m}$ (Nocentini, pers. comm.). It is noteworthy that in 1996-97 Oligochaeta and Chironomidae communities composed of an extremely small number of systematic entities were still present not only in the Buccione Basin, but also in the other basins of the lake, particularly those of Pettenasco and Omegna (Baudo et al. 2001).

The slowness with which, several years after the liming, the lake has been re-colonised by many systematic entities of Oligochaeta and Chironomidae is probably due to the marked increase in metal concentrations in the sediment, produced by the neutralisation of the water. It is also likely that changes in the lake water chemistry, especially in $\mathrm{pH}$, which very soon after the recovery intervention was showing values around or higher than 6 , encouraged the liberation in the water and the sediment of metals in ionic forms, which are more easily accumulated in benthic organisms through their body membranes or from food sources, but which are highly toxic (Campbell \& Stokes 1985; Gerhardt 1993).

Food is an important channel for the transfer of toxins from the surrounding environment to bottom organisms like Oligochaeta and Chironomidae, which feed largely on algae, detritus, and associated microorganisms, which have sedimented to the bottom or are suspended in the water layers immediately above the bottom (Brinkhurst 1971; Berg 1995). In Lake Orta these particles are mostly autochthonous in origin, and 
come mainly from particulate matter produced in the water column and sedimented.

The toxins accumulating in benthic organisms may have a negative effect on their fecundity and their lifecycle, and may reduce markedly the numbers of systematic entities in the community (Wiederholm \& Dave 1989; Johnson et al. 1992). A drop in the number of Chironomidae taxa has for example been recorded frequently in environments contaminated by copper, chrome and zinc, like Lake Orta (St. Louis 1993; Lindegaard 1995). However, it should be stressed that the effects of these toxins on the organisms depend on the type of metal available, and on abiotic factors like $\mathrm{pH}$ and temperature, as well as on biotic factors like size and body weight, or stage of development (Chapman et al. 1980; Gerhardt 1993; Lindegaard 1995). Nevertheless, there are populations that are able to survive in the presence of high metal concentrations, because they possess efficient detoxification mechanisms, or can lower the amount of metal accumulated in their bodies either through excretion or, as in the case of insects, through moulting and emergence. Populations which live for generations in contaminated environments can also develop a genetic resistance to metals (Gerhardt 1993; Lindegaard 1995).

In the Buccione Basin, the macrobenthic fauna is still qualitatively poor in the sub-littoral and deep layers, where some species, particularly the more tolerant forms such as Tubifex tubifex, Chironomus thummi gr. and Procladius, are present in considerable quantities. It will probably require some years before these zones become re-populated with systematic entities characteristic of environments with low pollution, particularly other Tubificidae species. It should be remembered that these species live several centimetres below the surface of the sediment, where the values of metal concentrations may, as in Lake Orta, be higher than those of the surface layers (Beltrami et al. 1999).

Interestingly in this context, some Tubificidae species were found in 1996-97 in the Tortirogno Basin (Baudo et al. 2001); compared to the other basins of the lake, this one has better environmental conditions, mainly because of low values of metals in the sediment. At a depth of $25 \mathrm{~m}$, besides Limnodrilus hoffmeisteri and Tubifex tubifex, the presence of Branchiura sowerbyi and Aulodrilus pluriseta was discovered. In the same basin in 1997-98, significant quantities of Aulodrilus pluriseta were observed between 8 and $10 \mathrm{~m}$ (Baudo, pers. comm.). At the same depth abundant populations of larval forms were recorded among the Chironomidae. They belong to the genera Cladotanytarsus and Tanytarsus among Tanytarsini, and to some genera of Chironomini, such as Pagastiella orophila, Cladopelma gr. lateralis, Paracladopelma gr. camptolabis, commonly found in the littoral-sublittoral zones of subalpine lakes.
A qualitatively more varied macrobenthos has been recorded in the other basins of the lake, especially in the shallow layers. In 1993-94, a higher number of Oligochaeta species, in particular Naididae, and larval forms of Chironomidae, was found in the littoral layers of the Buccione Basin than in the deeper layers. Also present in the community were Trichoptera, with the species Mystacides azurea and Ecnomus tenellus, Megaloptera, with the genus Sialis, and Diptera Ceratopogonidae, which were observed in the lake before liming.

Between 1993 and 1998 (De Margaritis 1995; Bielli \& Tesauro 2001), representatives of other taxonomic groups were found around the perimeter of the lake at depths above $4 \mathrm{~m}$. Of particular note among these are the Oligochaeta Lumbriculidae and Enchytraeidae, and the Insecta Odonata, Ephemeroptera, Plecoptera and Coleoptera. Also present were Turbellaria, Hydracarina, and Crustacea (Asellus aquaticus).

The structure of the littoral and the profundal macrobenthos will undoubtedly undergo further changes in the next few years, but the paucity of earlier data on the deep-water fauna will make it difficult to compare the future situation of the community with the situation existing prior to the pollution of the lake. Nevertheless, it is unlikely that a stable and qualitatively well-organised community will be established, particularly in the deep layers, as long as there is no reduction in metal concentrations at sediment level. All the same, the future evolution of the macrobenthos should be monitored, also because the lake's trophic state will probably increase as a consequence of large inputs of phosphorus from the watershed. These could cause extensive changes in the physical-chemical and biological parameters of the water and the sediments, with major implications for the colonisation of benthic organisms.

\section{REFERENCES}

Ambrosetti, W., L. Barbanti \& A. Calderoni. 1992. Il controllo delle operazioni di liming in rapporto all'idrochimica lacustre ed al ciclo termico. In: Calderoni, A. \& R. de Bernardi (Eds). Atti Conv. Orta, un lago da salvare: le fasi del suo recupero. Orta, 9-10 aprile 1990. Documenta Ist. ital. Idrobiol., 38: 31-52.

Anlauf, A. \& D. Neumann. 1997. The genetic variability of Tubifex tubifex (Müller) in 20 populations and its relation to habitat type. Arch. Hydrobiol., 139: 145-162.

Baldi, E. 1949. Il Lago d'Orta, suo declino e condizioni attuali. Mem. Ist. ital. Idrobiol., 5: 145-188.

Ballarè, G., E. Bielli, G. Fornara \& P. Masseroni. 1992. Qualità e utilizzo delle acque litorali del Lago d'Orta. In: Calderoni, A. \& R. de Bernardi (Eds). Atti Conv. Orta, un lago da salvare: le fasi del suo recupero, Orta, 9-10 Aprile 1990. Documenta Ist. ital. Idrobiol., 38: 83-94.

Barton, D.R. 1988. Distribution of some common benthic invertebrates in nearshore Lake Erie, with emphasis on depth and type of substratum. J. Great Lakes Res., 14: 3443.

Baudo, R \& M. Beltrami. (2001). Chemical composition of Lake Orta sediments. J. Limnol.: (in press).

Baudo, R., A.M. Nocentini, A. Occhipinti \& M. Sabolla. (2001). Benthos of Lake Orta in the year 1996. J. Limnol.: (in press). 
Baudo, R., L. Amantini, F. Bo, R. Cenci, P. Hannaert, A. Lattanzio, G. Marengo \& H. Muntau. 1989. Spatial distribution patterns of metals in the surface sediments of Lake Orta (Italy). Sci. Total Env., 87/88: 117-128.

Beltrami, M., D. Rossi \& R. Baudo. 1999. Phytotoxicity assessment of Lake Orta sediments. Aquatic Ecosystem Health \& Management, 2: 391-401.

Berg, M.B. 1995. Larval food and feeding behaviour. In: Armitage, P.D., P.S. Cranston \& L.C.V. Pinder (Eds). The Chironomidae: Biology and ecology of non-biting midges. Chapman \& Hall, London: 137-168.

Bertoni, R. \& C. Callieri. 1982. Yearly variation of parameters involved in the organic carbon cycle in pelagic and littoral zones of Lago Maggiore. Mem. Ist. ital. Idrobiol., 46: 161190.

Bertoni, R. \& C. Callieri. 1993. Organic carbon trend during oligotrophication of Lago Maggiore. In: de Bernardi, R., R. Pagnotta \& A. Pugnetti (Eds). Strategies for lake ecosystems beyond 2000. Selected papers. Mem. Ist. ital. Idrobiol., 52: 191-205.

Bielli, E. \& M. Tesauro. (2001). The littoral benthon community of Lake Orta after liming: a comparison between summer 1993 and summer 1998. J. Limnol.: (in press).

Bonacina, C. \& G. Bonomi. 1984. I grandiosi effetti ambientali determinati dalle prime fasi del disinquinamento del Lago d'Orta. Documenta Ist. ital. Idrobiol., 2: 24 pp.

Bonacina, C \& G. Bonomi. 1985. Advances in the recovery of Lake Orta after three years of functioning of the new treatment plants. Proc. Int. Congr. Lakes Pollution and Recovery. Rome, April 15-18, 1985: 175-180.

Bonacina, C. \& A. Pasteris. 2001. Zooplankton of Lake Orta after liming: an eleven years study. J. Limnol., 60(1): 101109.

Bonacina, C., G. Bonomi \& C. Monti. 1986. Oligochaete cocoon remains as evidence of past lake pollution. Hydrobiologia, 143: 395-400.

Bonacina, C., G. Bonomi, L. Barbanti, R. Mosello \& D. Ruggiu. 1988. Recovery of an industrially acidified, ammonium and heavy metals polluted lake (Lake Orta, N. Italy), due to the adoption of treatment plants. Verh. int. Ver. Limnol., 23: 535-544.

Boriani, A. \& R. Sacchi. 1974. The "Insubric" and other tectonic lines in the southern Alps (NW Italy). Mem. Soc. Geol. It., 13: 1-11.

Brinkhurst, R.O. 1971. Distribution and ecology. In: Brinkhurst, R.O. \& B.G.M. Jamieson (Eds). Aquatic Oligochaeta of the world. Oliver \& Boyd, Edinburgh: 104-146.

Calderoni, A. \& R. de Bernardi. 1992. Le vicende ambientali del Lago d'Orta dal degrado al recupero. In: Calderoni, A. $\&$ R. de Bernardi (Eds). Atti Conv. Orta, un lago da salvare: le fasi del suo recupero. Orta, 9-10 aprile 1990. Documenta Ist. ital. Idrobiol., 38: 1-23.

Calderoni, A. \& G.A. Tartari. 2001. Evolution of the water chemistry of Lake Orta after liming. J. Limnol., 60(1): 6978.

Calderoni, A., R. de Bernardi \& R. Mosello. 1993. Lago d'Orta ecosystem recovery by liming. In: Jørgensen, S.E. (Ed.). Management of lake acidification. International Lake Environment Committee. Guidelines of lake management, 5: 105-144.

Calderoni, A., R. Mosello \& R. de Bernardi. 1997. Le fasi recenti del recupero del Lago d'Orta. In: Mosello R. \& G. Giussani (Eds). Evoluzione recente della qualità delle acque dei laghi profondi sudalpini. Documenta Ist. ital. Idrobiol., 61: 55-72.

Campbell, P.G.C. \& P.M. Stokes. 1985. Acidification and toxicity of metals to aquatic biota. Can. J. Fish. aquat. Sci., 42: 2034-2049.

Cattaneo, A. 1992. The anthropogenically stressed periphyton of Lake Orta, Italy. Hydrobiologia, 234: 111-121.
Chapman, P.M., L.M. Churchland, P.A. Thomson \& E. Michnowsky. 1980. Heavy Metal Studies with Oligochaetes. In: Brinkhurst, R.O. \& D.G. Cook (Eds). Aquatic Oligochaete Biology. Plenum Press, New York \& London: 477-502.

Colosi, A. 1924. Dendrocelum lacteum (Müller) nel Lago d'Orta. Natura, 15: 37-38.

Corbella, C., V. Tonolli \& L. Tonolli. 1958. I sedimenti del Lago d'Orta testimoni di una disastrosa polluzione cuproammoniacale. Mem. Ist. ital. Idrobiol., 10: 9-50.

De Margaritis, G. 1995. Indagine sulle prime fasi del ripopolamento del Lago d'Orta (Bacino di Buccione) da parte della fauna macrobentonica dopo il risanamento del lago mediante l'intervento di "liming". Tesi di Laurea, Università degli Studi di Milano: $115 \mathrm{pp}$.

Donald, G.L. \& C.G. Paterson. 1977. Effects of preservation on wet weight biomass of Chironomid larvae. Hydrobiologia, 53: 75-80.

Driscoll, C.T., W.A. Ayling, J.F. Fordham \& L.M. Oliver. 1989. The chemical response of lakes treated with $\mathrm{CaCO}_{3}$ to reacidification. Can. J. Fish. aquat. Sci., 46: 258-267.

Eriksson, F., E. Hornstrom, P. Mossberg \& P. Nyberg. 1983. Ecological effects of lime treatment of acidified lakes and rivers in Sweden. Hydrobiologia, 101: 145-164.

Gerhardt, A. 1993. Review of impact of heavy metals on stream invertebrates with special emphasis on acid conditions. Wat., Air, Soil Pollut., 66: 289-314.

Gorham, E. \& J.E. Sanger. 1975. Fossil pigments in Minnesota lake sediments and their bearing upon the balance between terrestrial and aquatic inputs to sedimentary organic matter. Verh. int. Ver. Limnol., 19: 2267-2273.

Guilizzoni, P. \& A. Lami. 1990. Ricerche paleolimnologiche sul Lago d'Orta. Documenta Ist. ital. Idrobiol., 28: 53-69.

Guilizzoni, P., G. Bonomi, G. Galanti \& D. Ruggiu. 1983. Relationship between sedimentary pigments and primary production: evidence from core analyses of twelve Italian lakes. Hydrobiologia, 103: 103-106.

Håkanson, L. \& M. Jansson. 1983. Principles of lake sedimentology. Springer Verlag, Berlin Heidelberg: 316 pp.

Hoffmann, K.H., J. Seuss, E. Hipp \& U.A. Seldmaier. 1986. Aerobic and anaerobic metabolism in Tubifex, a freshwater oligochaete. Zool. Beitr., 30: 153-170.

Holm-Hansen, O. \& R. Rieman. 1978. Chlorophyll $\alpha$ determination: improvement in methodology. Oikos, 30: 438-447.

Johnson, R.K., L. Eriksson \& T. Wiederholm. 1992. Ordination of profundal zoobenthos along a trace metal pollution gradient in northern Sweden. Wat., Air, Soil Pollut., 65: 339-351.

Keller, W., L.A. Molot, R.W. Griffiths \& N.D. Yan. 1990. Changes in the zoobenthos community of acidified Bowland Lake after whole-lake neutralization and lake trout (Salvelinus namaycush) reintroduction. Can. J. Fish. aquat. Sci., 47: 440-445.

Kelly, G. 1991. Effects of liming on water chemistry and biota. In: Olem, H. (Ed.). Liming acidic surface waters. Lewis Publishers, Michigan: 139-192.

Lacqua, P., V. Bignami \& G. Galbusera. 1983. Indagine chimica sulle acque reflue provenienti dalla rete fognaria dei comuni di San Maurizio d'Opaglio e Pella in entrata all'impianto di depurazione consortile di Lagna. Cons. Dep. Acque Reflue Cusio. Rapporto tecnico: $10 \mathrm{pp}$.

Landhal, C.C. \& B. Nagel. 1978. Influence of the season and of preservation methods on wet and dry weights of larvae of Chironomus plumosus. J. Int. Revue ges. Hydrobiol., 63: 405-410.

Lenz, J. 1977. Seston and its main components. In: Rheinheimer, G. (Ed.). Microbial Ecology of a Brackish Water Environment. Ecological studies, Verlag, New York, 25: $37-60$.

Lewis, M.N. \& F.H. Weiberhan. 1981. Chemistry of a $7.5 \mathrm{~m}$ sediment core from Lake Valencia, Venezuela. Limnol. Oceanogr., 26: 907-924. 
Lindegaard, C. 1995. Classification of water bodies and pollution. In: Armitage, P.D., P.S. Cranston \& L. C. V. Pinder (Eds). The Chironomidae: Biology and ecology of non biting-midges. Chapman \& Hall, London: 385-404.

Mc Murtry, M.J., D.G. Rapport \& K.E. Chua. 1983. Substrate selection by tubificid Oligochaetes. Can. J. Fish. aquat. Sci., 40: 1639-1646.

Merilainen, J.J. \& J. Hynynen. 1990. Benthic invertebrates in relation to acidity in Finnish forest lakes. In: Kauppi, P., P. Anttila \& K. Kenttamies (Eds). Acidification in Finland. Springer Verlag, Berlin Heidelberg: 1029-1049.

Milbrink, G. 1980. Oligochaete communities in pollution biology: The European situation with special reference to lakes in Scandinavia. In: Brinkhurst, R.O. \& D.G. Cook (Eds). Aquatic Oligochaete Biology. Plenum Press, New York \& London: 433-455.

Monti, R. 1930. La graduale estinzione della vita nel Lago d'Orta. Rend. R. Ist. Lomb. Sc. Lett., 63: 75-94.

Morabito, G. \& M. Curradi. 1997. Phytoplankton community structure of a deep subalpine italian lake (Lake Orta, N. Italy) four years after the recovery from acidification by liming. Int. Revue ges. Hydrobiol., 82: 487-506.

Morabito, G., D. Ruggiu \& P. Panzani. 2001. Trends of phytoplankton characteristics and their communities in pre- and post-ling time in Lake Orta (1984-1998). J. Limnol., 60(1): 91-100.

Moretti, G.P. 1954a. La distribuzione dei Tricotteri lungo il litorale del Lago d'Orta. Mem. Ist. ital. Idrobiol., 8: 257270.

Moretti, G.P. 1954b. Il limnobio neritico dei Tricotteri a testimonianza dell'attuale situazione biologica del Lago d'Orta. Boll. Soc. Eustachiana, 47: 59-117.

Nalepa, T.F. \& N.A. Thomas. 1976. Distribution of macrobenthic species in Lake Ontario in relation to sources of pollution and sediment parameters. J. Great Lakes Res., 2: $150-163$.

Oioli, G.F. 1969. Ricerche sulla fauna litorale del Lago d'Orta. Tesi di Laurea, Università degli Studi di Milano: $140 \mathrm{pp}$.

Parona, C. 1880. Prime ricerche intorno ai protisti del Lago d'Orta, con cenno della loro corologia italiana. Boll. Scientifico, Pavia 2: 12 pp.
Pavesi, P. 1879. Nuova serie di ricerche sulla fauna pelagica nei laghi italiani. Rend. R. Ist. Lomb. Sc. Lett., 63: 3-22.

Raddum, G.G., P. Brettum, D. Matzow, J. P. Nilssen, A. Skov, T. Svealv \& R.F. Wright. 1986. Liming the acid Lake Hovvatn, Norway: a whole-ecosystem study. Wat. Air Soil Pollut., 31: 721-763.

Ruggiu, D. 1969. Benthic Ciliates in the profundal of Lake Orta (Northern Italy). Verh. int. Ver. Limnol., 17: 255-258.

Sabolla, M. 1998. Ricolonizzazione del lago d'Orta da parte della fauna macrobentonica dopo l'intervento di risanamento mediante liming. Tesi di Laurea, Università degli Studi di Milano: 108 pp.

Sanger, J.E. \& E. Gorham. 1970. The diversity of pigments in lake sediments and its ecological significance. Limnol. Oceanogr., 15: 59-69.

St. Louis, V.L. 1993. Element concentrations in chironomids and their abundance in the littoral zone of acidified lakes in north-western Ontario. Can. J. Fish. aquat. Sci., 50: 953-963.

Swain, E.B. 1985. Measurement and interpretation of sedimentary pigments. Freshwat. Biol., 15: 53-75.

Tartari, G.A. \& R. Mosello. 1997. Metodologie analitiche e controlli di qualità nel laboratorio chimico dell'Istituto Italiano di Idrobiologia. Documenta Ist. ital. Idrobiol., 60: $160 \mathrm{pp}$.

Tesauro, M., E. Bielli, M. Cotta Ramusino \& B. Rossaro. 1995. The littoral benthon of Lake Orta after liming. Mem. Ist. ital. Idrobiol., 53: 213-230.

Wetzel, R.G. 1970. Recent and postglacial production rates of a marl lake. Limnol. Oceanogr., 15: 491-503.

Wetzel, R.G. 1975. Limnology. Saunders Company: 743 pp.

Wiederholm, T. \& G. Dave. 1989. Toxicity of metal polluted sediments to Daphnia magna and Tubifex tubifex. Hydrobiologia, 176/177: 411-417.

Wiederholm, T. \& L. Eriksson. 1977. Benthos of an acid lake. Oikos, 29: 261-267.

Wingberg, G.G. 1971. Methods for the estimation of production of aquatic animals. Academic Press, London \& New York: $175 \mathrm{pp}$. 